\title{
Role of Citicoline in the Management of Traumatic Brain Injury
}

\author{
Julio J. Secades (1)
}

check for

updates

Citation: Secades, J.J. Role of Citicoline in the Management of Traumatic Brain Injury. Pharmaceuticals 2021, 14, 410. https://doi.org/10.3390/ ph14050410

Academic Editor: Paweł Grieb

Received: 30 March 2021

Accepted: 24 April 2021

Published: 26 April 2021

Publisher's Note: MDPI stays neutral with regard to jurisdictional claims in published maps and institutional affiliations.

Copyright: (C) 2021 by the author. Licensee MDPI, Basel, Switzerland. This article is an open access article distributed under the terms and conditions of the Creative Commons Attribution (CC BY) license (https:// creativecommons.org/licenses/by/ $4.0 /)$.
Medical Department, Ferrer, 08029 Barcelona, Spain; jsecades@ferrer.com

\begin{abstract}
Head injury is among the most devastating types of injury, specifically called Traumatic Brain Injury (TBI). There is a need to diminish the morbidity related with TBI and to improve the outcome of patients suffering TBI. Among the improvements in the treatment of TBI, neuroprotection is one of the upcoming improvements. Citicoline has been used in the management of brain ischemia related disorders, such as TBI. Citicoline has biochemical, pharmacological, and pharmacokinetic characteristics that make it a potentially useful neuroprotective drug for the management of TBI. A short review of these characteristics is included in this paper. Moreover, a narrative review of almost all the published or communicated studies performed with this drug in the management of patients with head injury is included. Based on the results obtained in these clinical studies, it is possible to conclude that citicoline is able to accelerate the recovery of consciousness and to improve the outcome of this kind of patient, with an excellent safety profile. Thus, citicoline could have a potential role in the management of TBI.
\end{abstract}

Keywords: CDP-choline; citicoline; pharmacological neuroprotection; brain ischemia; traumatic brain injury; head injury

\section{Introduction}

Traumatic brain injury (TBI) is among the most devastating types of injury and can result in a different profile of neurological and cognitive deficits, and even death in the most severe cases. TBI represents a large portion of the global injury burden and is caused mainly by falls, especially in old patients, and road injuries, often affecting young patients [1]. The effects of TBI are not limited to the patient suffering from this injury; it also affects families and societies, with a relevant financial burden. There is a solid agreement that the management of TBI must be focused to avoid brain injury. Upon clinical examination [2], TBI is classified into mild, moderate, and severe, based on the scores of the Glasgow Coma Scale (GCS). Such categories have been found to be predictive of a patient's long-term outcome, although other measures and models have also been tested, as biomarkers [2,3].

As explained, the management of TBI has to be focused on the reduction of the severity of the sequelae and to improve the recovery of these. The improvement in monitoring and in the knowledge of the pathophysiology of TBI could change current management, allowing for more adequate interventions that could improve the final outcomes, reducing the associated disabilities [4]. This improvement has been based on a better understanding of the complex pathophysiology of TBI. Neuroprotection is considered one of the treatments among the improvements in the treatment of TBI [5-9].

Among the biochemical mechanisms implicated in the pathophysiology of TBI, the inflammatory processes [10-16], and the impairment of the phospholipid metabolism and its consequences [17-35] play an important role. Because of these pathophysiological conditions, there is agreement on the need for drugs that may have a protective and restorative or reparative effect on the nervous system [36-40], the so-called "traumatic penumbra" being the target of their effect [22]. Citicoline is the generic name for cytidine- $5^{\prime}-$ diphosphocholine or CDP-choline, which is a normal component of the human metabolism as an intermediate in the synthesis of phosphatidylcholine, the main phospholipid in cellular membranes (Figure 1), and, when it is administered exogenously as a drug, has a 
wide range of biochemical and pharmacological actions becoming a putative treatment for some neurological diseases [41], including TBI [22].

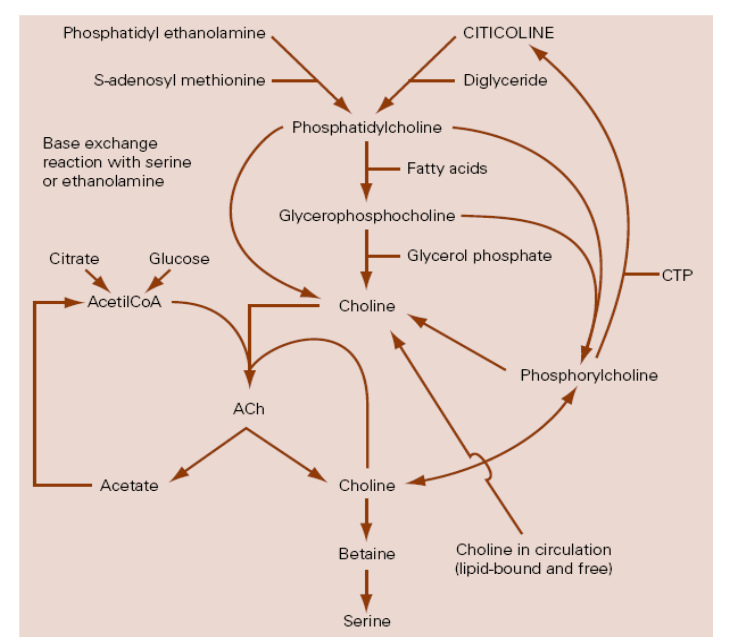

Figure 1. Relationship between citicoline and choline metabolism, cerebral phospholipids and acetylcholine. ACh: Acetylcholine; CTP: Cytidin triphosphate (Adapted with permission from Secades, J.J.; Lozano, R. Traumatismos craneoencefálicos: revisión fisiopatológica y terapéutica. Aportaciones de la citicolina. Excerpta Medica. Amsterdam, The Netherlands, 1991. Copyright 1985 Ferrer Internacional S.A.).

\section{Experimental Data}

Table 1 summarizes the most relevant preclinical studies evaluating the therapeutic efficacy and the mechanism of action of citicoline in different experimental models.

It has been demonstrated that citicoline is able to prevent degradation of choline and ethanolamine phospholipids during brain ischemia [42], and to restore the integrity of the blood-brain barrier [43]. Other old experimental studies have shown the protective effects of citicoline in neuronal cultures in hypocapnic conditions [44], and positive effects on the threshold for the arousal reaction, reducing the duration of coma induced by different mechanisms [45-48]. For example, Ogashiwa et al. [48] analyzed the dose-response of citicoline on post-traumatic disturbances of consciousness in mice. They used groups of 10 mice for every dose of citicoline administered by IV. The dose-escalation of citicoline was $0,1,2,4,8,15,30,60,125$, and $250 \mathrm{mg} / \mathrm{Kg}$ and the assignment was randomized. Control group received comparable volumes of saline solution. The injury (mechanical impact) was induced $10 \mathrm{~min}$ after the administration of the drug. The degree of concussion was assessed measuring the time interval from the onset of coma and the return of the righting reflex (RR time) and the time between the onset of coma and subsequent appearance of spontaneous movement (SM time). A significant dose-dependent relationship was found on RR time in animals that received the doses of $60 \mathrm{mg} / \mathrm{Kg}$ or higher. Furthermore, for the same level of doses, a significant reduction of SM times was found, thus the authors concluded that with doses not less than $60 \mathrm{mg} / \mathrm{kg}$ IV, citicoline showed a statistically significant improvement in the disturbances of consciousness during the acute phase of head injury in mice.

Citicoline can increase the incorporation and the metabolism of glucose and reduce the levels of lactate in the brain during ischemia [49]. Citicoline can modulate the activity of some enzymes, such as cholinephosphotransferase or phospholipases, especially phospholipase A2 [50-55]. Arrigoni et al. [51] demonstrated that following a cryogenic injury of the brain, within the tissue surrounding the necrotic lesion, there was a clear activation of the phospholipase A2 at 2 and $4 \mathrm{~h}$ after the lesion that participated in the phospholipid breakdown. They also detected an activation of the cholinephosphotransferase $2 \mathrm{~h}$ post-injury, that could correspond to an early phospholipid resynthesis. For their experiment, the authors used cryogenic brain injury in rabbits that were randomly assigned to the control group or to the lesion group. Animals were killed by decapitation 2, 4 and $8 \mathrm{~h}$ after the 
lesion. Eighteen injured animals received $200 \mathrm{mg} / \mathrm{Kg}$ PO of citicoline $5 \mathrm{~h}$ before the injury, except for the $8 \mathrm{~h}$-injured group which received $100 \mathrm{mg} / \mathrm{Kg}$ PO $5 \mathrm{~h}$ before and $1 \mathrm{~h}$ after the injury. Eighteen injured animals were used as controls. The enzymatic activities were measured in the brain homogenate obtained after the sacrifice. As described, a significant increase of the activity of the phospholipase A2 was detected 2 and $4 \mathrm{~h}$ after the injury. In injured animals, citicoline administration was associated with a significant prevention of the phospholipase A2 stimulation as compared to the untreated injured animals, whereas the drug did not affect the phospholipase A2 activity in control treated animals. In this model, citicoline did not affect the cholinephosphotransferase activity in any experimental conditions. The authors concluded that the beneficial effects of citicoline might be explained by a prevention of destruction rather than an enhancement of reconstruction of phospholipids. Kitazaki et al. [54] studied the effects of citicoline on membrane-associated phospholipase A2 using a synaptosome fraction from rat cerebral cortex and a crude membrane fraction from rat platelets. Citicoline, at a dose 1-10 mM, inhibited the activity of both enzymes I a dose-dependent manner, being this inhibition competitive.

In some experimental models, citicoline provided significant protection against the lethality, improving the survival quality [56-58]. Algate et al. [56] compared the effects of repeated oral administration of citicoline and vehicle on the EEG changes induced by epidural brain compression in anesthetized cats. Animals were treated with citicoline at doses 0.5 or $2.5 \mathrm{~g} / \mathrm{Kg}$ per day for 5 days. After this 5 days of treatment, animals were anesthetized and the epidural compression was induced by a balloon catheter and platinum electrodes were placed stereotactically to record EEG. Citicoline-treated cats exhibited a statistically significant increase in resistance to the effects of mechanical compression of the brain when compared with the vehicle-treated group. The onset of abnormal EEG waveforms occurred at greater levels of brain compression in citicoline-treated animals, and these animals were less susceptible to cardiac and respiratory disorders. A statistically significant protection against the lethal effects of epidural compression was also noted in treated animals. The authors concluded that repeated oral treatment with citicoline can provide some protection against the effects of acute mechanical compression of the brain. Kondo [58] studied the effects of citicoline $(15-20 \mathrm{mg} / \mathrm{Kg})$ slowly injected into the common carotid artery or IV in a model of progressive brain compression in cats. Citicoline markedly improved the disturbances of consciousness and the EEG records. It has been possible to detect the labelled drug in the brain, notably in the affected areas in a model of cold brain injury in rats [59]. Boismare et al. [60] studied the effects of citicoline in a model of craniocervical trauma without direct blow ("whiplash") in rats. The lesion was induced by means of a fierce acceleration and deceleration applied to the animals. Two days after the lesion animals presented an asymmetry in the activity of the laterocervical muscles, a postural dysregulation of the brain circulation, and disturbances in conditioned avoidance responses. These alterations were related with an increase of the cerebral norepinephrine splitting. The intraperitoneal injection of citicoline $(20 \mathrm{mg} / \mathrm{Kg})$ one hour after the trauma prevented all the modifications on the central catecholamine metabolism and suppressed the behavioral disorders noticed in the control animals. In many different experimental models of brain edema a significant effect of citicoline on the reduction of the edema has been demonstrated, associating this effect with the restoration of the activity of the membranous ATPases that facilitate the reabsorption of the edema [17,18,61-66]. Clendenon et al. [61] studied the effects of citicoline $(100-200 \mathrm{mg} / \mathrm{Kg}$ IV) on the ATPase activity in a model of spinal cord injury by impact in dogs. Two minutes after the injury a significant decrease of the $\mathrm{Na}+/ \mathrm{K}+$-ATPase activity was found, and at $30 \mathrm{~min}$, also decreased activity of the Mg++-ATPase. Administration of citicoline 5 min after injury prevented the decrease of the $\mathrm{Mg}++-\mathrm{ATPase}$ activity, whereas the decrease of the $\mathrm{Na}+/ \mathrm{K}+-$ ATPase activity was not prevented, probably because it was already inactivated to a low level before the administration of the drug. Cohadon et al. [62] demonstrated that in the development of vasogenic cerebral edema there was a progressive quantitative and qualitative impairment of mitochondrial-ATPase and of $\mathrm{Na}+\mathrm{K}+$-ATPase using a model of 
cryogenic brain edema in rats. Citicoline was administered $24 \mathrm{~h}$ after the injury at doses of $20 \mathrm{mg} / \mathrm{Kg}$ and continued daily until the sacrifice of the animals. Citicoline was able to correct this disturbed enzymatic activity and at the same time reduce the extent of the cerebral edema. Cervós-Navarro and Lafuente [63,64] studied the effects of citicoline in a model of ultraviolet-induced brain edema in cats. After the induction of the edema by exposure to ultraviolet light, eight cats were treated with a single dose of citicoline of $100 \mathrm{mg} / \mathrm{Kg} \mathrm{1,8}$ and $16 \mathrm{~h}$ after the lesion. Eight cats were used as controls and they received the same volume of solvent alone $(1 \mathrm{~mL} / \mathrm{Kg})$. Tissue water content was measured by a microgravimetric method. It was shown that animals treated with citicoline had a less volumetric increase than those animals treated with placebo, demonstrating an effect of the drug accelerating the reabsorption of brain edema. Majem et al. [65] analyzed the effects of multiple oral doses of citicoline on the bioelectric changes induced by brain edema in a model of cryogenic brain edema in rats. Treated animals $(n=8)$ receive oral citicoline at a dose $1 \mathrm{~g} / \mathrm{Kg} / \mathrm{d}$ for 8 days, starting immediately after the lesion. Treated animals showed a significant increase of the theta band during their awake state at the expense of a decrease of delta band as compared to control animals. A minor interindividual dispersion in each of the frequency bands was observed in treated animals, that somehow reflected the protective effects of the drug. Roda [66] in his study assessing the effects of citicoline on two different animal models of cryogenic brain edema, demonstrated the efficacy of the drug by means of a significant reduction of the Evans blue extravasation and that this effect was more evident when the drug was administered before the induction of the injury. Citicoline has been able to show a significant effect on microvascular permeability during experimental endotoxemia [67] and in models of early burn edema [68], postulating for a significant anti-inflammatory effect of the drug.

The effects of exogenous administration of citicoline $(100 \mathrm{mg} / \mathrm{Kg} / \mathrm{d} / 18 \mathrm{~d}$ IP beginning 1 day postinjury) on the motor consequences, spatial memory capacity, and acetylcholine levels in some areas of the brain, such as hippocampus and neocortex were analyzed in an experimental model of traumatic brain injury by a controlled lateral impact in a total of 50 rats. In the motor study, animals treated with citicoline had a significantly longer balance period than animals in the control group. In addition, the treatment with citicoline was significantly associated with less cognitive deficits. This effect could be explained by the rapid increase in acetylcholine production seen after a single administration of citicoline, in microdialysis studies [69].

Plataras et al. [70] investigated the effect of different citicoline concentrations (0.1-1 mM) on acetylcholinesterase, $\mathrm{Na}+\mathrm{K}+$-ATPase and $\mathrm{Mg}++-\mathrm{ATPase}$ activities in homogenates of adult rat whole brain and in pure (nonmembrane bound) enzymes. After a 1-3 h citicoline preincubation, this drug induced a maximal stimulation of $20-25 \%(p<0.001)$ for acetylcholinesterase and $50-55 \%(p<0.001)$ for Na+/K+-ATPase, but it did not influence $\mathrm{Mg}++-\mathrm{ATPase}$ activity. Citicoline can stimulate brain acetylcholinesterase and $\mathrm{Na}+/ \mathrm{K}+-$ ATPase independently of acetylcholine and noradrenaline and these effects could account for the clinical effects of the drug [70].

Başkaya et al. [71] examined the effect of citicoline on secondary injury factors, brain edema and blood-brain barrier breakdown, after TBI using a model of controlled cortical impact in rats. Brain edema was evaluated using the wet-dry method $24 \mathrm{~h}$ postinjury, and blood-brain barrier breakdown was evaluated by measuring Evans blue dye extravasation with fluorescein $6 \mathrm{~h}$ after TBI. After the injury, treated animals received intraperitoneal injections of citicoline $(50,100$, or $400 \mathrm{mg} / \mathrm{kg}$ two times after TBI $(n=8-10$ animals in each group)) and controls animals received saline solution (8 animals). TBI produced an increase in the water content and in measuring Evans blue dye extravasation in the injured cortex and the ipsilateral hippocampus. Citicoline at a dose of $50 \mathrm{mg} / \mathrm{kg}$ had no significant effect. At a dose of $100 \mathrm{mg} / \mathrm{kg}$, citicoline attenuated Evans blue dye extravasation in both regions, although it reduced brain edema only in the injured cortex. In both regions, $400 \mathrm{mg} / \mathrm{kg}$ of citicoline significantly decreased brain edema and blood-brain barrier breakdown. Thus, the authors demonstrated a dose-dependent neuroprotective effect of citicoline in a model 
of experimental TBI, suggesting that this drug could be an effective neuroprotective agent on secondary injuries that appear following TBI.

Dempsey et al. [72] investigated whether citicoline protects the hippocampal neurons after controlled cortical impact-induced TBI in adult rats. Citicoline $(100,200$, and $400 \mathrm{mg} / \mathrm{Kg}$ ) or saline were injected intraperitoneally into the animals twice (immediately postinjury and $6 \mathrm{~h}$ postinjury). Seven days after the injury, the rats were neurologically evaluated and killed, and the number of hippocampal neurons was estimated by examining thionine-stained brain sections. By 7 days postinjury, there was a significant amount of neuronal death in the ipsilateral hippocampus in the CA2 $(53 \pm 7 \%, p<0.05)$ and CA3 $(59 \pm 9 \%, p<0.05)$ regions and a contusion (volume $34 \pm 8 \mathrm{~mm}^{3}$ ) in the ipsilateral cortex compared with sham-operated control animals. Rats subjected to TBI also displayed severe neurological deficit at 7 days postinjury. Treating rats with citicoline at doses of 200 and $400 \mathrm{mg} / \mathrm{Kg}$ significantly prevented TBI-induced neuronal loss in the hippocampus, decreased cortical contusion volume, and improved neurological recovery.

Menku et al. [73] demonstrated a synergistic effect in the association of propofol with citicoline in an experimental model of TBI in rats, resulting in a higher reduction of the lipidic peroxidation when the drugs were administered together, concluding that this combination therapy may become a feasible option for the treatment of head injury.

Jacotte-Simancas et al. [74], using a model of controlled cortical impact injury in rats, studied the effects of citicoline and/or voluntary physical exercise on the related memory deficits and on neurogenesis and neuroprotection. Forty-eight male Sprague Dawley albino rats, six-weeks old, were randomly assigned to one of five experimental conditions, according to whether they were sham operated or had received TBI, and according to the treatment administered: citicoline vs. vehicle and exercise (E) vs. sedentary conditions. Citicoline $(200 \mathrm{mg} / \mathrm{kg})$ was administered by intraperitoneal route $4 \mathrm{~h}$ after surgery, and thereafter every $24 \mathrm{~h}$ until completing five injections. Citicoline improved memory deficits at short and long-term, while physical activity only in the long-term test. Physical activity increased cell proliferation and neurogenesis, and citicoline reduced the interhemispheric differences in the volume of the hippocampal formation. The combined effects of citicoline and physical exercise did not show any synergy, even the present data could suggest that the combined treatment with citicoline and physical exercise should be avoided in patients after TBI.

Qian et al. [75] designed an experimental study to investigate the neuroprotective effects of citicoline on a model of closed head injury in rats. Citicoline $(250 \mathrm{mg} / \mathrm{Kg}$ IV $30 \mathrm{~min}$ and $4 \mathrm{~h}$ after injury) lessened body weight loss, and improved neurological functions significantly at 7 days. Treatment with citicoline was associated with a decrease of brain edema and of blood-brain barrier permeability, an enhancement of the activities of superoxide dismutase and the levels of glutathione, and with a reduction of the levels of malondialdehyde and lactic acid. Moreover, citicoline suppressed the activities of calpain, and enhanced the levels of calpastatin, myelin basic protein and $\alpha$ II-spectrin in traumatic tissue $24 \mathrm{~h}$ after injury. Citicoline was also able to attenuate the axonal and myelin sheath damage in corpus callosum and the neuronal cell death in hippocampal CA1 and CA3 subfields 7 days after injury. Authors consider that these findings provide additional support for the use of citicoline in the management of TBI.

Gan et al. [76], in an in vivo TBI zebrafish model, demonstrated that microglia, considered the resident macrophages of the central nervous system, accumulated rapidly after the injury. To perform its function, activated microglia secreted two types of cytokines, including proinflammatory interleukins and anti-inflammatory factors, helping to remove injured neurons and restore the homeostasis of the central nervous system. Citicoline was able to induce a further activation of microglia, and this was related with the reduction of neuronal apoptosis and the promotion of neuronal proliferation around the lesioned site associated with the use of citicoline.

Furthermore, some positive neuroprotective effects of citicoline have been published on different models of traumatic spinal cord lesion [77-80]. 
Table 1. Summary of preclinical studies evaluating the therapeutic efficacy and the mechanism of action of citicoline in TBI.

\begin{tabular}{|c|c|c|c|c|c|c|}
\hline Author & Year & Study Design & Experimental Model & Insult & Dose & Main Results \\
\hline Tsuchida et al. [59] & 1967 & Comparative study & Rats & Cold injury & $100 \mu \mathrm{c}{ }^{3} \mathrm{H}$-CDP-choline IP & $\begin{array}{l}\text { Significant incorporation of the labelled drug } \\
\text { in the affected areas of the brain }\end{array}$ \\
\hline Kondo [58] & 1968 & Comparative study & Male cats $(2.5-4 \mathrm{Kg})$ & Epidural compression & $15-20 \mathrm{mg} / \mathrm{Kg}$ intracarotid & Significant increase of survival rates \\
\hline Boismare et al. [60] & 1977 & Comparative study & Rats & Whiplash injury & $20 \mathrm{mg} / \mathrm{Kg}$ IP & $\begin{array}{l}\text { Significant prevention on catecholamines } \\
\text { changes in brain and suppression of } \\
\text { behavioral disorders }\end{array}$ \\
\hline Cohadon F. et al. [62] & 1979 & Comparative study & Rabbits $(\sim 2.5 \mathrm{Kg})$ & Cryogenic lesion & $\begin{array}{l}20 \mathrm{mg} / \mathrm{Kg} / 4 \mathrm{~d} \text { IV (starting } 24 \mathrm{~h} \\
\text { after injury) }\end{array}$ & $\begin{array}{l}\text { Significant restoration of the activity of the } \\
\text { mitochondrial ATPase and of the } \\
\text { membranous Na+/K+-ATPase. Acceleration } \\
\text { of the reabsorption of brain edema. }\end{array}$ \\
\hline \multirow[b]{2}{*}{ Roda J.E. [66] } & \multirow[b]{2}{*}{1980} & \multirow[b]{2}{*}{ Comparative study } & Wistar Rats & Cryogenic lesion & $\begin{array}{l}6 \mathrm{mg} / \mathrm{Kg} / 12 \mathrm{~h} \text { IP } \\
\text { Starting } 24 \mathrm{~h} \text { before the lesion and } \\
\text { continued until sacrifice }\end{array}$ & $\begin{array}{l}\text { Significant reduction of the extravasation of } \\
\text { blue Evans }\end{array}$ \\
\hline & & & Cats & Cryogenic lesion & $\begin{array}{c}15 \mathrm{mg} / \mathrm{Kg} / 12 \mathrm{~h} \mathrm{IP} \\
\text { Starting } 24 \mathrm{~h} \text { before the lesion or } \\
2 \mathrm{~h} \text { after the lesion and continued } \\
\text { until sacrifice }\end{array}$ & $\begin{array}{l}\text { Significant reduction of the extravasation of } \\
\text { blue Evans. Better results when } \\
\text { administered before the lesion }\end{array}$ \\
\hline Algate et al. [56] & 1983 & Comparative study & Male cats $(2.65-3.65 \mathrm{Kg})$ & Epidural compression & $0.5 \mathrm{~g} / \mathrm{Kg} / 5 \mathrm{~d} \mathrm{PO}$ & $\begin{array}{c}\text { Significant increase in resistance to effects of } \\
\text { mechanical compression }\end{array}$ \\
\hline Ogashiwa M. et al. [48] & 1985 & $\begin{array}{l}\text { Comparative randomized } \\
\text { study }\end{array}$ & Mice & Mechanical impact & $1-250 \mathrm{mg} / \mathrm{Kg} \mathrm{IV}$ & Significant dose-effect on duration of coma \\
\hline Kitazaki T. et al. [54] & 1985 & Comparative study & Rats & $\mathrm{N} / \mathrm{A}^{\mathrm{a}}$ & $1-10 \mathrm{mM}$ & $\begin{array}{l}\text { Dose-dependent inhibition of } \\
\text { activity of PLA2 }{ }^{b}\end{array}$ \\
\hline Clendenon et al. [61] & 1985 & Comparative study & Mongrel dogs (8-12 Kg) & Impact injury at spinal cord & 100-200 mg/Kg IV & $\begin{array}{l}\text { Prevention of the decrease of } \\
\mathrm{Mg}^{2+} \text {-dependent ATPase activity }\end{array}$ \\
\hline Lafuente J.V. et al. [63]. & 1986 & $\begin{array}{l}\text { Comparative randomized } \\
\text { study }\end{array}$ & Male cats & $\begin{array}{c}\text { Ultraviolet-induced brain } \\
\text { edema }\end{array}$ & $20 \mathrm{mg} / \mathrm{Kg} \mathrm{IV}$ & $\begin{array}{l}\text { Significant acceleration of the reabsorption } \\
\text { of brain edema }\end{array}$ \\
\hline Majem X. et al. [65] & 1986 & Comparative study & Male rats $(180-200 \mathrm{~g})$ & Cryogenic lesion & $1 \mathrm{~g} / \mathrm{Kg} / 8 \mathrm{~d} \mathrm{PO}$ & $\begin{array}{l}\text { Significant increase of theta activity and } \\
\text { decrease of delta activity on EEG }\end{array}$ \\
\hline Arrigoni E. et al. [51] & 1987 & $\begin{array}{l}\text { Comparative randomized } \\
\text { study }\end{array}$ & Female rabbits $(2.0-2.5 \mathrm{Kg})$ & Cryogenic lesion & $200 \mathrm{mg} / \mathrm{Kg}$ PO & $\begin{array}{l}\text { Dose-dependent complete inhibition of } \\
\text { PLA2 }{ }^{\mathrm{b}} \text { activation }\end{array}$ \\
\hline Cervós-Navarro J. et al. [64] & 1990 & $\begin{array}{l}\text { Comparative randomized } \\
\text { study }\end{array}$ & Mongrel cats $(2.5-4.5 \mathrm{Kg})$ & $\begin{array}{c}\text { Ultraviolet-induced brain } \\
\text { edema }\end{array}$ & $100 \mathrm{mg} / \mathrm{Kg}$ IV (3 doses in $24 \mathrm{~h}$ ) & $\begin{array}{l}\text { Significant acceleration of the reabsorption } \\
\text { of brain edema }\end{array}$ \\
\hline
\end{tabular}


Table 1. Cont.

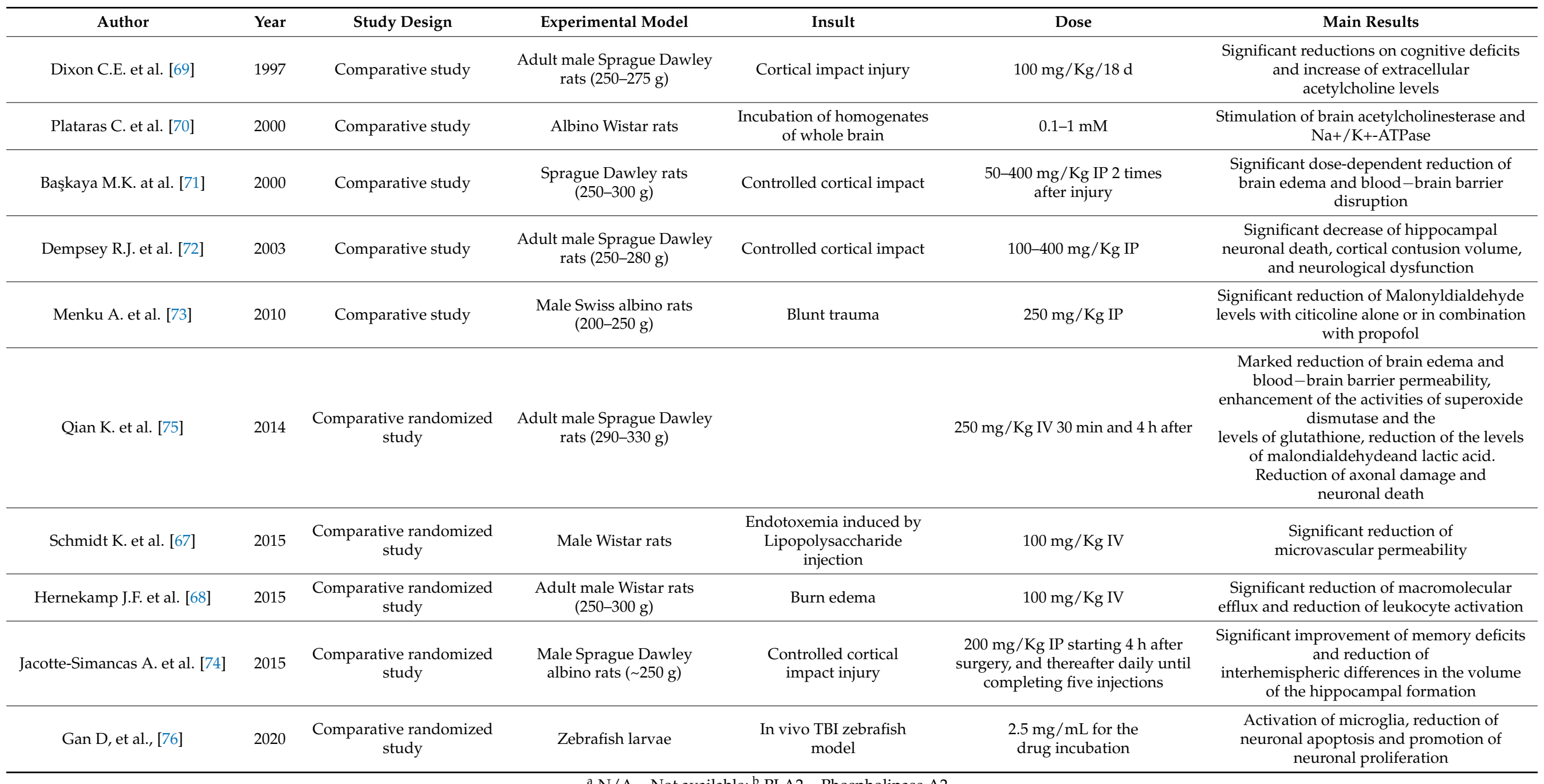

${ }^{\mathrm{a}}$ N $/ \mathrm{A}=$ Not available; ${ }^{\mathrm{b}}$ PLA2 = Phospholipase A2. 
Citicoline holds some biochemical, pharmacological, and pharmacokinetic characteristics to be a potentially useful drug for the management of TBI [81] and citicoline has an appropriate profile for the treatment of the different brain ischemia related disorders, having different neuroprotective and neurorestorative properties (Table 2) [82-85].

Table 2. Main actions of citicoline on experimental models of TBI.

- Protection and restoration of neuronal membrane.

- Normalization of phospholipid content in membranes.

- Normalization of neuronal membrane functions.

- Normalization of ionic exchange across neuronal membrane.

- $\quad$ Restoration of some enzymatic activities (CTP:phosphocholine cytidyltransferase, ... ).

- Improvement of neurotransmission (acetylcholine, dopamine, etc.).

- Improvement of cerebral metabolism.

- $\quad$ Restoration of the activity of membrane-bound ATPases.

- Inhibition of the activity of phospholipases, avoiding the release of free radicals, and second messengers.

- Empowerment of antioxidative and anti-inflammatory mechanisms.

- Acceleration of the reabsorption of brain edema.

- Reduction of the volume of brain ischemic lesions.

- Inhibition of apoptosis.

- Activation of cell repair mechanisms and neuroplasticity.

\section{Clinical Experiences of Patients with Traumatic Brain Injuries}

As it has been shown in the previous section about the experimental data showing that citicoline can induce significant positive effects in different experimental models of TBI, citicoline seems to be a suitable drug for the management of patients suffering TBI. Thus, it is possible to say that citicoline has a pleiotropic effect on several steps of the ischemic cascade involved in the development of the TBI [84].

Many years ago, the effect of citicoline stimulating the ascending reticular activating system at the brain stem level was postulated to explain the effects of the drug on the consciousness level [84]. As citicoline could be considered as a valid pharmacological treatment for TBI, many clinical studies have been performed over time to assess if the drug would have beneficial effects in the treatment of patients with TBI.

There are early published clinical data showing that citicoline can lead to recovery from neurological clinical symptoms and a return to a conscious state with an excellent safety profile [86].

\subsection{Clinical Studies on Mild, Complicated to Severe Head Injuries}

Table 3 summarizes chronologically all clinical studies evaluating the effects of citicoline in the management of patients with mild, complicated to severe traumatic brain injury.

The first double-blind randomized and placebo-controlled clinical trial was presented in 1979 by Misbach at al. [87]. In this study, the authors concluded that the use of citicoline was associated with better recovery in patients with severe TBI.

In another double-blind study, performed by Ayuso et al. in 1979, it was demonstrated the effectiveness of citicoline to treat patients with memory disorders of an organic base, in that case induced by bilateral electroshock [88].

De la Herrán et al. [89], in an open study with the 32 patients with severe TBI among other types of brain injuries, concluded that the administration of citicoline accelerated normalization of the consciousness state. Similar results and conclusions were obtained in other double-blind studies performed by Espagno et al. [90] and by Carcasonne and LeTourneau [91], the last one performed in children population.

Richer and Cohadon [92] performed a randomized, double-blind and placebo-controlled trial in a sample of 60 patients with severe TBI. Citicoline was administered at a dose of $750 \mathrm{mg} / \mathrm{d}$ intravenously for 6 days, and then intramuscularly for 20 days more. At 60 days, the number of patients who had recovered consciousness was significantly greater in the 
group receiving citicoline. At 90 days, it was also found that the highest rate of recovery of motor deficits was associated with the treatment with citicoline.

Lecuire and Duplay [93], in a double-blind study, compared the effects of citicoline $(750 \mathrm{mg} / \mathrm{d} / 10 \mathrm{~d}$ IV) to those of meclofenoxate $(3 \mathrm{~g} / \mathrm{d} / 10 \mathrm{~d}$ IV) in a sample of 25 patients (14 patients treated with citicoline and 11 patients treated with meclofenoxate). Statistical analysis of the results demonstrated significant effects in the citicoline treated group regarding the resolution of consciousness disorders, EEG pattern, and functional recovery. Shortly after, the same authors confirmed these positive results in an open label study performed in a group of 154 patients with TBI injury [94]. Lecuire [95] conducted another double-blind study comparing piracetam $(6 \mathrm{~g} / \mathrm{d})$ versus citicoline $(750 \mathrm{mg} / \mathrm{d})$ in a group of 40 patients with head injury. The results of the study showed a better result on consciousness status, vegetative and electric, and on the global final improvements in the group of patients treated with citicoline.

Cohadon et al. [96] demonstrated the clinical efficacy of citicoline in a double-blind placebo-controlled trial in a sample of 60 patients with severe TBI. A group of 30 patients was treated with citicoline $(750 \mathrm{mg} /$ intravenously for 6 days and continued up to 20 days more with intramuscular administration). In the treated group a shortening of the comatose period and an acceleration of the recovery of neurological deficits, especially in the motor area, were observed, these differences being statistically significant compared to placebo. The authors attributed these positive results to the effect of the drug on brain edema. Deleuze et al. [97] correlated the effectiveness of citicoline with its effect on the cerebral metabolism, reflected in a significant reduction of lactate levels in cerebrospinal fluid after the treatment.

Ogashiwa et al. [48] performed a study in a sample of patients with disturbances of consciousness associated with stroke, TBI or brain tumours. Fifty-one patients were treated with citicoline $(1000 \mathrm{mg} / \mathrm{d} / 7 \mathrm{~d}$ IV) and 50 patients with the same characteristics were used as controls. The effects were evaluated using the principal component analysis score and the global improvement rate. The results of the principal component analysis scoring correlated closely with those of the global improvement rate, the effects in the citicoline-treated group being significantly greater than those obtained in the control group. Citicoline was more effective on the items related to the performance than on the verbal factor. These authors considered the drug to be safe, and they even administered the drug by the intrathecal route in some cases $[98,99]$.

In another controlled study, De Blas et al. [100] evaluated the effects of citicoline on the short- and long-term evolution in a group of 100 patients with head injuries, compared with a group of 100 patients treated conventionally. The results obtained suggested that the addition of citicoline to the conventional treatment regimen was associated with a decrease in the length of post-traumatic coma and the incidence of neurological and psychological sequelae, accelerating the recovery of these kind of deficits.

Raggueneau and Jarrige [101] published the results of a national inquiry conducted in 24 neurosurgical intensive care units in France. The authors obtained information on 921 cases of severe TBI. Among the total sample, 219 patients were treated with citicoline. This, then, allowed the comparison of the results obtained between patients treated and not treated with citicoline. The improvement of the outcome for all patients was significantly linked to citicoline treatment. Nevertheless, no effects on the mortality rate were seen associated with the use of the drug.

Calatayud Maldonado et al. [102] conducted a single-blind randomized clinical trial in a sample of 216 patients with moderate to severe TBI with the objective of assessing the influence of the addition of citicoline to the standard treatment for head injury. One hundred and fifteen patients received treatment with citicoline (up to $4 \mathrm{~g} / \mathrm{d}$ parenterally). The total duration of the treatment varied according to the evolution of the patient. The analysis of the results showed that citicoline significantly decreased hospital stay. Similarly, the treatment with citicoline was associated with a significant better global outcome, as evaluated with the Glasgow Outcome Scale, that was more relevant in the subgroup of 
patients with severe TBI. The duration of outpatient follow-up was also reduced in the group of patients treated with citicoline.

Lozano [103] reported the results of a randomized study to assess the impact of the use of citicoline therapy on the evolution of patients with severe TBI. Citicoline was administered to 39 patients at a dose ranging from 3 to $6 \mathrm{~g} / \mathrm{d}$ by intravenous infusion for 2 weeks. The results were compared with another group of patients with the same characteristics and not treated with citicoline. After 14 days of treatment, cerebral edema was significantly reduced or normalized in a higher number of patients treated with citicoline. Mean hospital stay was also significantly reduced in the active treatment group (28.718 \pm 21.6 days) in comparison with control group $(37.323 \pm 35.22$ days; $p<0.001)$. Regarding the final outcome, evaluated with the Glasgow Outcome Scale, it was a trend to have a better outcome in the group receiving the active treatment, but these differences did not reach statistical significance, probably due to the small sample size.

Lazowski et al. [104] performed a randomized and placebo-controlled study on a sample of 28 patients with traumatic brain injury caused by isolated head trauma. Citicoline was administered at a dose of $1 \mathrm{~g}$ IV for 14 days in addition to typical treatment. The GCS and the Glasgow Outcome Scale (GOS) were used to control patients up to 30 days. In the citicoline-treated group the analysis found no correlation between the GCS scores in day 7 and day 14, and this lack of correlation could be interpreted as a result of treatment with citicoline, and the significant correlation found on the GCS at 14 and 21 days could be interpreted as an expanded effect of treatment up to 21 days. In the citicoline-treated group, the GCS score at 21 days was significantly correlated with GOS scores at 30 days, showing the protective effect of the used drug.

Hinev al. [105] in their study observed that $80 \%$ of patients with severe head trauma recovered from neurological symptoms and unconsciousness, concluding that the use of citicoline was associated with reduced coma duration and accelerated recovery of neurological disturbances in patients with severe head trauma, highlighting the safety of the drug.

Krishna et al. [106] conducted a randomized, single-blind, placebo-controlled, singlecenter, prospective trial in a sample of 100 patients. Patients were randomized to receive citicoline $(2 \mathrm{~g} / \mathrm{d} / 60 \mathrm{~d} \mathrm{PO})$ or placebo and the evaluations of outcomes were made at discharge and after 30 and 90 days. The authors concluded that the rate of recovery was earlier in the citicoline group in terms of a shorter duration of stay, early gaining of full consciousness and relief from cognitive symptoms.

The Citicoline Brain Injury Treatment Trial (COBRIT) was a double-blind randomized and placebo-controlled trial with a special design $[107,108]$. The objective of the trial was to determine the ability of citicoline to positively affect the functional and cognitive status in patients with complicated mild, moderate, and severe TBI. The primary outcome of the study was the functional and cognitive status at 90 days. The outcome was measured by the nine components of the TBI Clinical Trials Network Battery, that includes the Trail Making Test (parts A and B), the extended Glasgow Outcome Scale (GOS-E), the California Verbal Learning Test II, the Controlled Oral Word Association Test, some of the tests included in the Wechsler Adult Intelligence Scale III (Processing Speed Index and Digit Span), and the Stroop Test (Parts 1 and 2). The sample size was calculated assuming an odds ratio (OR) of 1.4 or higher, and the final sample size was fixed as 1296 patients, after adding $15 \%$ for presumed losses. The patients were randomized to receive either citicoline $(2 \mathrm{~g} / \mathrm{d} / 90 \mathrm{~d})$ or placebo by enteral route within $24 \mathrm{~h}$ after injury. The clinical trial was stopped early for futility with 1213 patients included. Rates of favorable improvement for the GOS-E were $35.4 \%$ in the citicoline group and $35.6 \%$ in the placebo group. For the other scales, the rate of improvement ranged from $37.3 \%$ to $86.5 \%$ in the citicoline group and from $42.7 \%$ to $84.0 \%$ in the placebo group. There were no significant differences between groups at the 90-day evaluation: global OR: 0.98 (95\% CI: $0.83-1.15)$, nor at the 180-day evaluation: global OR 0.87 (95\% CI: 0.72-1.04). On the basis of the results obtained, the authors concluded that 
citicoline, compared with placebo, was not effective in the improvement of the functional and cognitive status of patients with TBI.

Despite the COBRIT trial being the largest study performed with citicoline in the management of TBI, there are some methodological issues that could question the validity and applicability of the results obtained. This study was an independent and academic study, financed by the US National Institute of Health, with a somewhat limited budget. A first point to consider was the sample size calculation that was based on an assumption of an OR of 1.4 as the effect of the treatment; however, this assumption was arbitrary and not based on previous data. Then, it looked as though the sample size was calculated based on the budget rather than on previous data. With a more realistic OR of 1.2 or less the sample size would have been much higher and unaffordable for the authors. Another key point to consider was the inclusion of mixed populations, including mild, moderate, and severe TBI. The pathophysiology and the evolution can be largely different among these groups. To consider these differences, it is mandatory to use a randomized and matched sample design, which was not used in the COBRIT trial. Thus, this is an evident source of heterogeneity, but it has not been considered as an important confounding factor in the analysis and interpretation of the data. Another point to take into the account was the atypical oro-enteral administration of the drug that is not approved in any country and has not previously been tested in any way. The use of this route of administration is not recommended in patients with moderate or severe TBI, at least in the first days. However, the most controversial point was the poor compliance of the treatment. A compliance of only $44.4 \%$ of patients having taken more than $75 \%$ of the medication expected is exceptionally low and needs to be explained, explanation that was not included in the publication of the trial. We must consider that not receiving the active treatment is not the same as not receiving the placebo, in terms of the standard of care being received. A placebo is a substance or treatment which is designed to have no therapeutic value. In other words, less than half of the patients in the active drug group received something close to a therapeutic dose of citicoline. Thus, this makes it exceedingly difficult to assume a lack of effect of the drug when the patients did not receive the proper treatment regimen.

El Reweny et al. [109] communicated the results of their study on patients with severe head injury. In their study 40 patients were allocated to 2 groups, where patients in Group I were treated with citicoline $(1 \mathrm{~g} / \mathrm{d} / 14 \mathrm{~d}$ IV) in front of patients in Group II that received conventional therapy. They found that those patients in Group I with brain edema had the best outcome. Indeed, patients in Group II with intracerebral hematoma had the worst outcome. The authors concluded that the addition of citicoline to the conventional therapy of patients with severe TBI offered a trend to improve the outcome. Interesting are the results obtained by Varadaraju and Ananthakishan [110], demonstrating a certain synergistic effect when citicoline was administered together with cerebrolysin, as the patients treated with this association had a better outcome than patients treated with citicoline alone. Titov et al. [111] also demonstrated a positive effect of the combination of citicoline and cerebrolysin in the management of TBI in the acute phase.

Trimmel et al. [112] investigated the potential role of citicoline administration in TBI patients treated at the Wiener Neustadt Hospital. In a retrospective subgroup analysis, they compared 67 patients at the study site treated with citicoline $(3 \mathrm{~g} / \mathrm{d} / 3$ weeks IV) and 67 matched patients from other Austrian centers not treated with citicoline. Patients with moderate to severe TBI were included. The analysis found a significant effect of citicoline, expressed by the reduction of the rates of mortality at the intensive care unit mortality ( $5 \%$ vs. $24 \%, p<0.01)$, during the hospital stay ( $9 \%$ vs. $24 \%, p=0.035)$, and after 6 months of follow up ( $13 \%$ vs. $28 \%, p=0.031)$. A significant reduction in the rates of unfavorable outcome ( $34 \%$ vs. $57 \%, p=0.015$ ) was also detected and in the observed vs. expected ratio for mortality ( 0.42 vs. 0.84$)$ in the citicoline group (Figure 2). Ahmadi et al. [113] published a double-blind, randomized clinical trial on 30 patients with severe TBI. According to the protocol (IRCT20140611018063N7) and the abstract, patients were randomly divided into three groups: A (control), B (citicoline $0.5 \mathrm{~g} / 12 \mathrm{~h} / 24 \mathrm{~d} \mathrm{IV}$ ), and C 
(citicoline $1.5 \mathrm{~g} / 12 \mathrm{~h} / 14 \mathrm{~d} \mathrm{IV}$ ), but once the authors explained the methods in the article, these groups changed to: A (citicoline $0.5 \mathrm{~g} / 12 \mathrm{~h} / 24 \mathrm{~d} \mathrm{IV}$ ), B (citicoline $1.5 \mathrm{~g} / 12 \mathrm{~h} / 14 \mathrm{~d} \mathrm{IV}$ ), and $C$ (placebo). This incongruence makes it difficult to interpret the results, because if the group assignment was the original, then a significant dose-dependent effect of citicoline can be found, but with the assignment stated in the paper, the results are difficult to interpret, but the authors concluded that citicoline had no positive effect on the outcome of such patients.

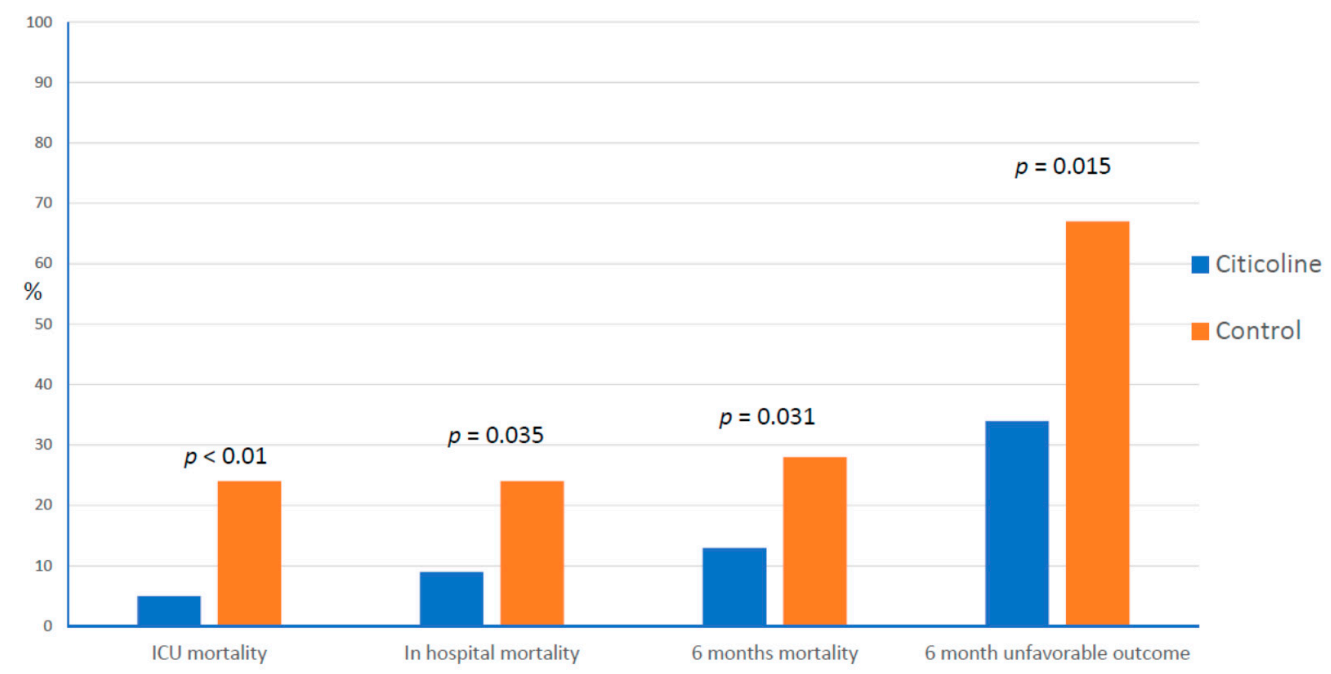

Figure 2. Effect of citicoline treatment on the rates of mortality and unfavorable outcome. ICU = Intensive Care Unit.

In recent years, the roles of inflammation and oxidative stress have been highlighted as targets to neuroprotection in the management of TBI [10-16]. Thus, the measurement of the effects of these neuroprotective therapies on the levels of established biomarkers of inflammation and oxidative stress could be of interest to evaluate the efficacy of such treatments.

Salehpour et al. $[114,115]$ assessed the effects of citicoline in a sample of patients with diffuse axonal injury in a double-blind and randomized clinical trial. The efficacy of citicoline was assessed by the measurement of malondialdehyde (MDA) levels in plasma as a marker of oxidative stress. The MDA levels at the different times of blood sampling improved significantly, whereas the control group showed no difference. The authors concluded that citicoline is an effective neuroprotective agent and can reduce MDA levels in patients with severe TBI and diffuse axonal injuries.

Shokouhi et al. [116] conducted a double-blind and randomized clinical trial on 58 patients with the diagnosis of diffuse axonal injury and severe TBI to investigate the effects of citicoline on serum levels of fetuin-A and matrix Gla-protein (MGP), that are related with the inflammation and the vascular calcification secondary to head trauma. The findings suggested that citicoline may have protective effects against inflammatory damage and vascular calcification in TBI patients through increasing plasma levels of fetuin-A and MGP. 
Table 3. Summary of clinical studies evaluating the effects of citicoline in the management of patients with mild to severe traumatic brain injury.

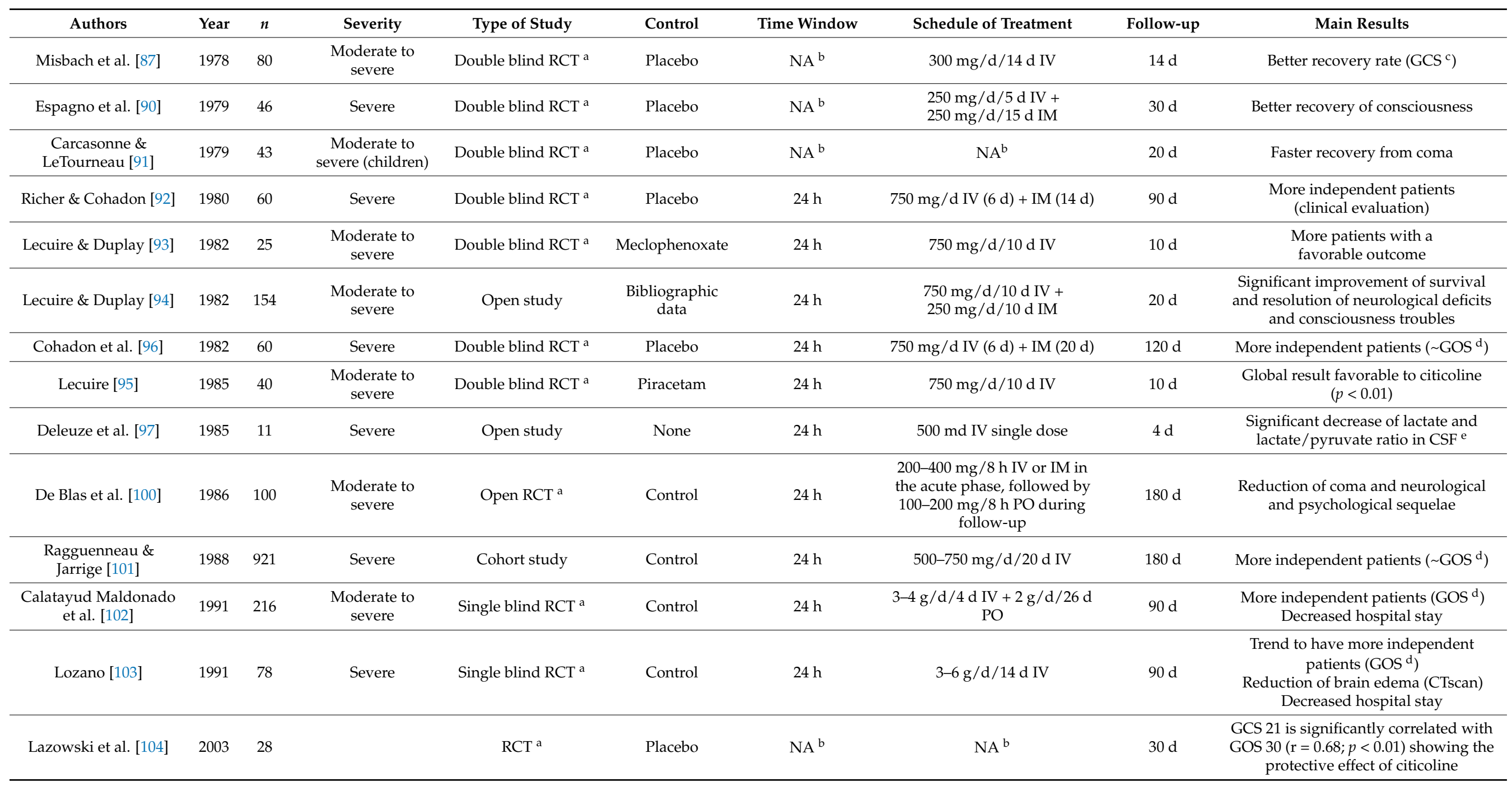


Table 3. Cont

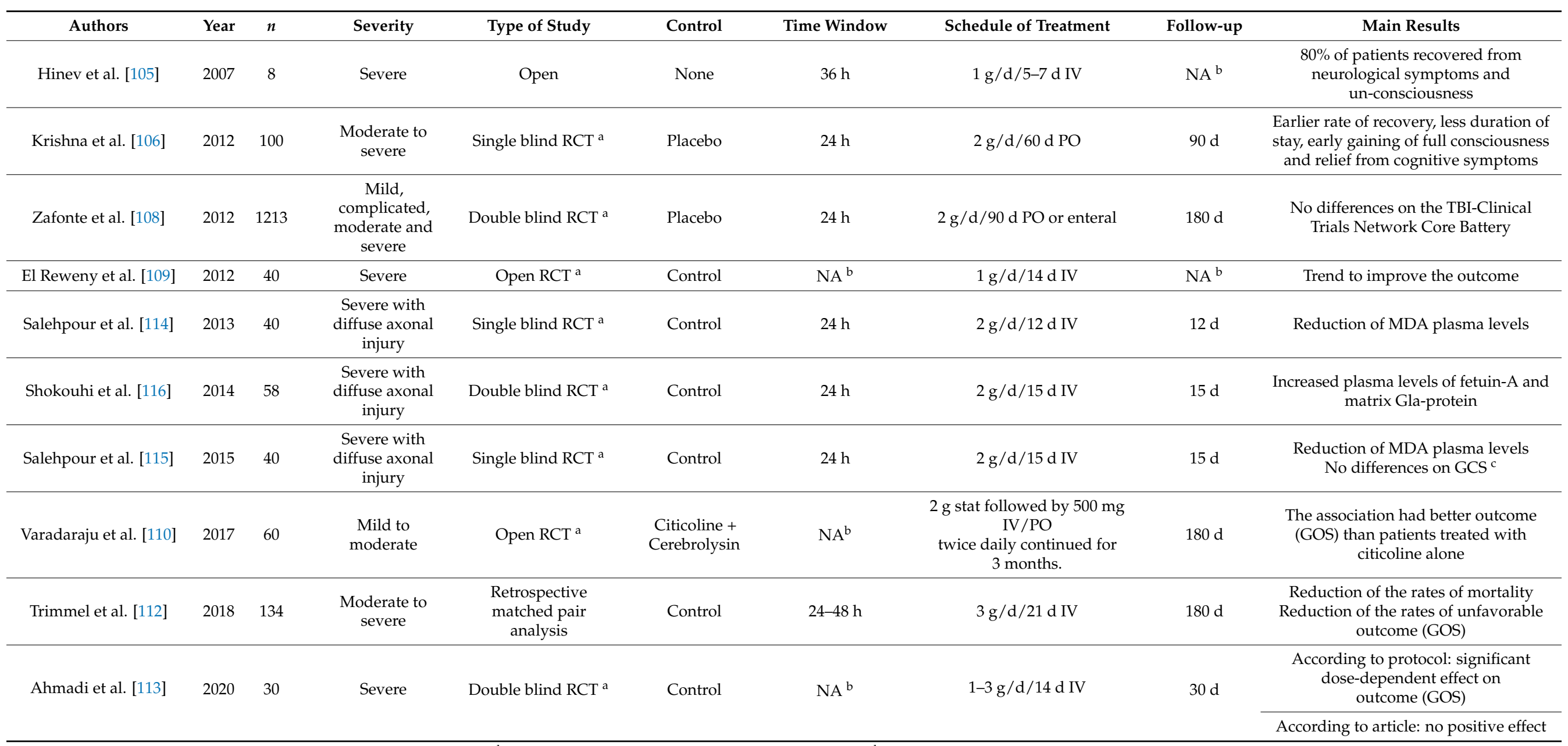




\subsection{Clinical Studies on Mild Head Injuries}

Levin [117] conducted a pilot double-blind, randomized and placebo-controlled study with 14 patients with post-concussion syndrome associated with a mild TBI. Treatment with citicoline $(1 \mathrm{~g} / \mathrm{d})$ for one month was associated with an improvement in memory tests, such as the Galveston Orientation and Amnesia Test, which was statistically significant as compared to placebo. The use of citicoline was linked to a higher symptomatic improvement, except for the gastrointestinal discomfort that was more frequent in the citicoline group, and for dizziness that was significantly more common in patients from the placebo group, at the end of the study.

However, Aniruddha et al. [118], in a simple-blind, randomized and placebo-controlled study performed in a sample of 44 patients with mild head injury were unable to evidence differences between citicoline and placebo in relation to the evolution of the postconcussion symptoms. Despite that, citicoline could be considered a therapeutic option for post-concussion syndrome associated with mild TBI [119].

\subsection{Clinical Studies on Cognitive Disorders Associated to TBI}

León-Carrión et al. [120-122] focused their investigations on the effects of citicoline on memory disorders associated to TBI. These authors assessed the effects of the administration of a single dose of $1 \mathrm{~g}$ of citicoline on cerebral blood flow measured by the 133Xe inhalation technique in patients with severe memory deficit after TBI. Two measurements were made: baseline and at $48 \mathrm{~h}$ later. Patients received the drug one hour before the first test. In the first measurement, a significant hypoperfusion was detected at the inferoposterior area of the left temporal lobe, an area related with memory. This hypoperfusion disappeared after citicoline administration, showing an objective effect of citicoline normalizing the cerebral blood flow in the affected areas. In another study, these authors demonstrated that neuropsychological rehabilitation associated with citicoline achieved improvements in all the evaluated areas, especially in verbal fluency and the word recall Luria test, these differences being statistically significant when compared with placebo. Thus, citicoline can be considered as a valid pharmacological option for the management of cognitive disorders associated with TBI [123], and this effect also induces an improvement in the quality of life [124].

\subsection{Meta-Analysis on the Effects of Citicoline in the Management of TBI}

In 2014, a meta-analysis based on 12 clinical studies was published [125]. A systematic search of the relevant terms was performed to identify comparative clinical trials of citicoline in the acute phase of patients with mild, moderate, or severe head injuries. The primary efficacy measure was the rate of independence or good outcome at the end of a scheduled follow-up period. This meta-analysis involved a total of 2706 patient. The use of citicoline was associated with a significant increase in the rates of independence with an OR of 1.815 (95\% CI: 1.3022.530), under the random effects model (Figure 3), and with an OR of 1.451 (95\% CI: 1.224-1.721), under the fixed effects model.

In a more recent meta-analysis [126], the authors found neutral effects of citicoline in the treatment of patients with TBI, but this meta-analysis was based only on studies published in English, and that is a well-known source of bias, enough to question the results obtained. To clarify the role of citicoline in the management of TBI, a new meta-analysis is ongoing, and the results will be available soon (PROSPERO CRD42021238998). 


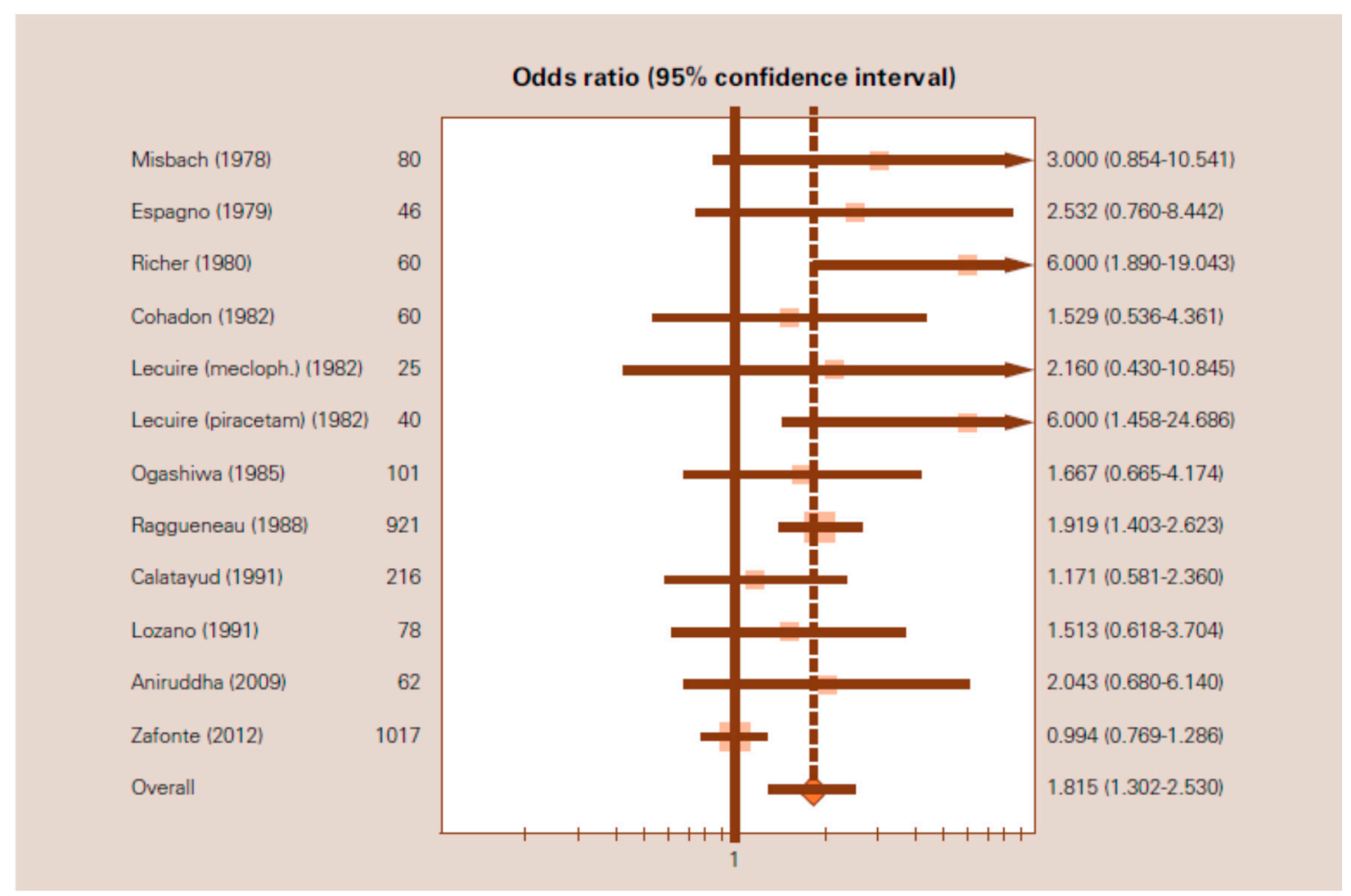

Figure 3. Forest plot of the meta-analysis of the effects of citicoline on independence after traumatic brain injury. OR $=1.815$ (95\% CI:1.302-2.530) based on the random-effects model. (From Secades, J.J. Citicoline for the Treatment of Head Injury: A Systematic Review and Meta-analysis of Controlled Clinical Trials. J. Trauma. Treat. 2014, 4, 227).

\section{Conclusions}

Citicoline, also named cytidine $5^{\prime}$-diphosphocholine or CDP-choline, is an intermediate in the generation of phosphatidylcholine from choline in mammals, the formation of endogenous citicoline being one of the principal steps in the biosynthetic pathway of phosphatidylcholine [84].

Independently of the administration route, oral or parenteral, citicoline splits in its two principal components, cytidine and choline. The absorption by the oral route is almost complete, and the bioavailability by the oral route is approximately the same as the intravenous route. Citicoline is widely distributed all around the body, crosses the blood-brain barrier and reaches the central nervous system (CNS). In the CNS, citicoline is incorporated into the phospholipid fraction of the cells, mainly at membranal and microsomal level, especially in neurons. Citicoline increases the biosynthesis of phosphatidylcholine in neuronal membranes, improves the brain energetic metabolism, and can modulate the levels of different neurotransmitters, such as acetylcholine, dopamine, and norepinephrine. Due to these biochemical and pharmacological actions, citicoline has demonstrated neuroprotective effects in hypoxic and ischemic conditions of the brain. As described in this review, citicoline can restore the activity of mitochondrial ATPase and membrane $\mathrm{Na}+/ \mathrm{K}+$-ATPase, and it is able to normalize the activity of phospholipase A2, and these actions leads to an acceleration of the reabsorption of cerebral edema in various experimental models. Thanks to its action as a choline donor, increasing the levels of acetylcholine, citicoline can improve the learning and memory performance in some animal models of brain aging [84].

In this review, it has been shown that in patients with moderate to severe TBI, the addition of citicoline into their standard therapeutic regimen could offer some benefits, as this drug can accelerate cerebral edema reabsorption and recovery, resulting in a shorter hospital stay and improved final outcome, with a higher independence rate among the patients treated with citicoline. However, despite the progressive increase of the doses, the 
beneficial effect of citicoline over time has been diluted in parallel with the improvement of the standards of care of TBI [125].

Citicoline is a safe drug, as shown by the toxicological studies conducted, without a significant systemic cholinergic effect and is a well-tolerated product as it has been shown in the Periodic Safety Reports made since its commercialization in the 1970s. Even in a Cochrane review for the evaluation of the effect of citicoline on elderly people with behavioral and cognitive disturbances [127], a lower rate of incidence of adverse events related with citicoline was demonstrated, in comparison with placebo.

The pharmacological and biochemical properties and the complex mechanisms of the action of citicoline suggest that this product is indicated for the management of acute stroke, both ischemic and hemorrhagic, TBI of varying severity, and cognitive disorders of different origins. The available data obtained from clinical studies in the management of patients with TBI indicate that citicoline can accelerate cerebral edema reabsorption and recovery, resulting in a shorter hospital stay and improved final outcome, with a higher independence rate among the patients treated with citicoline. These effects could be explained by the pharmacodynamics of the product and its pleiotropic effect on the mechanisms involved in the development of the TBI [41,84], some of these mechanisms are considered of interest as targets for the development of neuroprotective strategies for the management of TBI $[128,129]$. Citicoline also was able to induce an improvement of the cognitive disorders associated with TBI. No serious side effects have occurred in any series of patients treated with citicoline $[41,84,130]$.

Depending on the results of the new meta-analysis (PROSPERO CRD42021238998), it could be valuable to plan further clinical studies, specially focused on severe TBI and with higher doses of citicoline. However, no new large clinicals trials with citicoline in this field are expected.

Funding: This research received no external funding.

Institutional Review Board Statement: Not applicable.

Informed Consent Statement: Not applicable.

Data Availability Statement: No new data were created or analyzed in this study. Data sharing is not applicable to this article.

Acknowledgments: To Elisabet Torrademé Pascual for her help in the design of the graphical abstract of this review paper.

Conflicts of Interest: JJ Secades is a full-time employee on a company marketing citicoline.

\section{References}

1. GBD 2016 Traumatic Brain Injury and Spinal Cord Injury Collaborators. Global, regional, and national burden of traumatic brain injury and spinal cord injury, 1990-2016: A systematic analysis for the Global Burden of Disease Study 2016. Lancet Neurol. 2019, 18, 56-87. [CrossRef]

2. James, S.L.; Lucchesi, L.R.; Bisignano, C.; Castle, C.D.; Dingels, Z.V.; Fox, J.T.; Hamilton, E.B.; Liu, Z.; McCracken, D.; Nixon, M.R.; et al. Morbidity and mortality from road injuries: Results from the Global Burden of Disease Study 2017. Inj. Prev. 2020, 26 (Suppl. 1), i46-i56. [CrossRef] [PubMed]

3. Bogoslovsky, T.; Wilson, D.; Chen, Y.; Hanlon, D.; Gill, J.; Jeromin, A.; Song, L.; Moore, C.; Gong, Y.; Kenney, K.; et al. Increases of Plasma Levels of Glial Fibrillary Acidic Protein, Tau, and Amyloid $\beta$ up to 90 Days after Traumatic Brain Injury. J. Neurotrauma. 2017, 34, 66-73. [CrossRef] [PubMed]

4. Stocchetti, N.; Carbonara, M.; Citerio, G.; Ercole, A.; Skrifvars, M.B.; Smielewski, P.; Zoerle, T.; Menon, D.K. Severe traumatic brain injury: Targeted management in the intensive care unit. Lancet Neurol. 2017, 16, 452-464. [CrossRef]

5. Khellaf, A.; Khan, D.Z.; Helmy, A. Recent advances in traumatic brain injury. J. Neurol. 2019, 266, 2878-2889. [CrossRef]

6. Capizzi, A.; Woo, J.; Verduzco-Gutierrez, M. Traumatic Brain Injury: An Overview of Epidemiology, Pathophysiology, and Medical Management. Med. Clin. N. Am. 2020, 104, 213-238. [CrossRef]

7. Vella, M.A.; Crandall, M.L.; Patel, M.B. Acute Management of Traumatic Brain Injury. Surg. Clin. N. Am. 2017, 97, 1015-1030. [CrossRef]

8. Ng, S.Y.; Lee, A.Y.W. Traumatic Brain Injuries: Pathophysiology and Potential Therapeutic Targets. Front. Cell. Neurosci. 2019, 13, 528. [CrossRef] 
9. Stocker, R.A. Intensive Care in Traumatic Brain Injury Including Multi-Modal Monitoring and Neuroprotection. Med. Sci. 2019, 7, 37. [CrossRef]

10. Hosomi, S.; Ohnishi, M.; Ogura, H.; Shimazu, T. Traumatic brain injury-related inflammatory projection: Beyond local inflammatory responses. Acute Med. Surg. 2020, 7, e520. [CrossRef]

11. Jha, R.M.; Kochanek, P.M.; Simard, J.M. Pathophysiology and treatment of cerebral edema in traumatic brain injury. Neuropharmacology 2019, 145 Pt B, 230-246. [CrossRef]

12. Jarrahi, A.; Braun, M.; Ahluwalia, M.; Gupta, R.V.; Wilson, M.; Munie, S.; Ahluwalia, P.; Vender, J.R.; Vale, F.L.; Dhandapani, K.M.; et al. Revisiting Traumatic Brain Injury: From Molecular Mechanisms to Therapeutic Interventions. Biomedicines 2020, 8, 389. [CrossRef] [PubMed]

13. Chakraborty, S.; Skolnick, B.; Narayan, R.K. Neuroprotection Trials in Traumatic Brain Injury. Curr. Neurol. Neurosci. Rep. 2016, 16, 29. [CrossRef] [PubMed]

14. Mallah, K.; Couch, C.; Borucki, D.M.; Toutonji, A.; Alshareef, M.; Tomlinson, S. Anti-inflammatory and Neuroprotective Agents in Clinical Trials for CNS Disease and Injury: Where Do We Go from Here? Front. Immunol. 2020, 11, 2021. [CrossRef]

15. Sakai, S.; Shichita, T. Inflammation and neural repair after ischemic brain injury. Neurochem. Int. 2019, 130, 104316. [CrossRef]

16. Crupi, R.; Cordaro, M.; Cuzzocrea, S.; Impellizzeri, D. Management of Traumatic Brain Injury: From Present to Future. Antioxidants 2020, 9, 297. [CrossRef]

17. Boismare, F. Souffrance cérébrale: Comportement et neurotransmetteurs sur des modeles expérimentaux. In Symposium Internacional Souffrance Cérébrale et Précurseurs des Phospholipides; Laboratoires Cassenne-Takeda: Paris, France, 1980.

18. Cohadon, F.; Rigoulet, M.; Averet, M.; Arrigoni, E. Membrane damage in acute brain trauma. Nouv. Presse Med. 1989, 10, 147-155. [CrossRef]

19. Cohadon, F.; Rigoulet, M.; Guérin, B.; Vandendriessche, M. L'activité membranaire dans la souffrance cérébrale. Altérations des ATPases membranaires dans l'edème cérébral vasogénique. Restauration par un précurseur des phospholipides. In Symposium Internacional Souffrance Cérébrale et Précurseurs des Phospholipides; Laboratoires Cassenne-Takeda: Paris, France, 1980.

20. Cohadon, F. Physiopathologie des edèmes cérébraux. Rev. Neurol. 1987, 143, 3-20.

21. Rigoulet, M.; Guérin, B.; Cohadon, F.; Vandendriessche, M. Unilateral brain injury in the rabbit; reversible and irreversible damage of the membranal ATPases. J. Neurochem. 1979, 32, 535-541. [CrossRef]

22. Secades, J.J.; Lozano, R. Traumatismos Craneoencefálicos: Revisión Fisiopatológica y Terapéutica. Aportaciones de la Citicolina; Excerpta Medica: Amsterdam, The Netherlands, 1991.

23. Homayoun, P.; Parkins, N.E.; Soblosky, J.; Carey, M.E.; Rodriguez de Turco, E.B.; Bazan, N.G. Cortical impact injury in rats promotes a rapid and sustained increase in polyunsaturated free fatty acids and diacylglycerols. Neurochem. Res. 2000, 25, 269-276. [CrossRef] [PubMed]

24. Alberghina, M.; Giuffrida, A.M. Effect of hypoxia on the incorporation of [2-3H] glycerol and [1-14C]-palmitate into lipids of various brain regions. J. Neurosci. Res. 1981, 6, 403-419. [CrossRef] [PubMed]

25. Goldberg, W.J.; Dorman, R.V.; Horrocks, L.A. Effects of ischemia and diglycerides on ethanolamine and choline phosphotransferase activities from rat brain. Neurochem. Pathol. 1983, 1, 225-234.

26. Goldberg, W.J.; Dorman, R.V.; Dabrowiecki, Z.; Horrocks, L.A. The effects of ischemia and CDPamines on Na+,K+-ATPase and acetylcholinesterase activities in rat brain. Neurochem. Pathol. 1985, 3, 237-248.

27. Han, M.; Sun, T.; Chen, H.; Han, M.; Wang, D. Potential sphingosine-1-phosphate-related therapeutic targets in the treatment of cerebral ischemia reperfusion injury. Life Sci. 2020, 249, 117542. [CrossRef]

28. Solovieva, E.Y.; Farrahova, K.I.; Karneev, A.N.; Chipova, D.T. Phospholipids metabolism disorders in acute stroke. Zh. Nevrol. Psikhiatr. Im. S. S. Korsakova. 2016, 116, 104-112. [CrossRef]

29. Wang, X.; Zhang, L.; Sun, W.; Pei, L.L.; Tian, M.; Liang, J.; Liu, X.; Zhang, R.; Fang, H.; Wu, J.; et al. Changes of Metabolites in Acute Ischemic Stroke and Its Subtypes. Front. Neurosci. 2021, 14, 580929. [CrossRef]

30. Bazan, N.G. Docosanoids and elovanoids from omega-3 fatty acids are pro-homeostatic modulators of inflammatory responses, cell damage and neuroprotection. Mol. Aspects Med. 2018, 64, 18-33. [CrossRef]

31. Tayebati, S.K.; Marucci, G.; Santinelli, C.; Buccioni, M.; Amenta, F. Choline-Containing Phospholipids: Structure-Activity Relationships Versus Therapeutic Applications. Curr. Med. Chem. 2015, 22, 4328-4340. [CrossRef] [PubMed]

32. Chomova, M.; Zitnanova, I. Look into brain energy crisis and membrane pathophysiology in ischemia and reperfusion. Stress 2016, 19, 341-348. [CrossRef] [PubMed]

33. Zhao, Y.Y.; Miao, H.; Cheng, X.L.; Wei, F. Lipidomics: Novel insight into the biochemical mechanism of lipid metabolism and dysregulation-associated disease. Chem. Biol. Interact. 2015, 240, 220-238. [CrossRef]

34. Bogie, J.F.J.; Haidar, M.; Kooij, G.; Hendriks, J.J.A. Fatty acid metabolism in the progression and resolution of CNS disorders. Adv. Drug Deliv. Rev. 2020, 159, 198-213. [CrossRef]

35. Espinós, C.; Galindo, M.I.; García-Gimeno, M.A.; Ibáñez-Cabellos, J.S.; Martínez-Rubio, D.; Millán, J.M.; Rodrigo, R.; Sanz, P.; Seco-Cervera, M.; Sevilla, T.; et al. Oxidative Stress, a Crossroad between Rare Diseases and Neurodegeneration. Antioxidants 2020, 9, 313. [CrossRef]

36. Mizuma, A.; Yenari, M.A. Clinical perspectives on ischemic stroke. Exp. Neurol. 2021, 338, 113599. [CrossRef] [PubMed]

37. Zweifler, R.M. Membrane stabilizer: Citicoline. Curr. Med. Res. Opin. 2002, 18 (Suppl. 2), S14-S17. [CrossRef] [PubMed] 
38. Poddar, J.; Pradhan, M.; Ganguly, G.; Chakrabarti, S. Biochemical deficits and cognitive decline in brain aging: Intervention by dietary supplements. J. Chem. Neuroanat. 2019, 95, 70-80. [CrossRef] [PubMed]

39. Linnerbauer, M.; Rothhammer, V. Protective Functions of Reactive Astrocytes Following Central Nervous System Insult. Front. Immunol. 2020, 11, 573256. [CrossRef] [PubMed]

40. Saver, J.L. Targeting the brain: Neuroprotection and neurorestoration in ischemic stroke. Pharmacotherapy 2010, 30, 62S-69S. [CrossRef] [PubMed]

41. Jasielski, P.; Piędel, F.; Piwek, M.; Rocka, A.; Petit, V.; Rejdak, K. Application of Citicoline in Neurological Disorders: A Systematic Review. Nutrients 2020, 12, 3113. [CrossRef]

42. Horrocks, L.A.; Dorman, R.V. Prevention by CDP-choline and CDPethanolamine of lipid changes during brain ischemia. In Novel Biochemical, Pharmacological and Clinical Aspects of Cytidinediphosphocholine; Zappia, V., Kennedy, E.P., Nilsson, B.I., Galletti, P., Eds.; Elsevier Science Publishing: Amsterdam, The Netherlands, 1985; pp. 205-215.

43. Le Poncin-Lafitte, M.; Dutertem, D.; Lageron, A.; Rapin, J.R. CDP-choline et accident cérébral expérimental d'origine vasculaire. Agressologie 1986, 27, 413-416. [PubMed]

44. Mykita, S.; Golly, F.; Dreyfus, H.; Freysz, L.; Massarelli, R. Effect of CDP-choline on hypocapnic neurons in culture. J. Neurochem. 1986, 47, 223-231. [CrossRef]

45. Yasuhara, M.; Naito, H. Characteristic actions of CDP-choline on the central nervous system. Curr. Ther. Res. Clin. Exp. 1974, 16, 346-374. [PubMed]

46. Yasuhara, M.; Naito, H.; Tachibana, Y.; Yasuhara, A. An electrophysiological study on the effects of CDP-choline in the central nervous system. In Novel Biochemical, Pharmacological and Clinical Aspects of Cytidinediphosphocholine; Zappia, V., Kennedy, E.P., Nilsson, B.I., Galletti, P., Eds.; Elsevier Science Publishing: Amsterdam, The Netherlands, 1985; pp. $259-274$.

47. Martí-Viaño, J.L.; Selles, J.; Orts, A.; Marco, J.; Vega, F.; Espluges, J. Antagonismo del coma barbitúrico mediante productos alertizantes. Estudio experimental. Rev. Esp. Anest. Reanim. 1978, 25, 21-28.

48. Ogashiwa, M.; Sano, K.; Manaka, S.; Kitamura, K.; Kagawa, M.; Takeuchi, K. Effectiveness of CDP-choline on disturbance of consciousness (DOC): 1. An experimental study of concussive head injury in mice. 2. A controlled trial in patients with DOC. In Novel Biochemical, Pharmacological and Clinical Aspects of Cytidinediphosphocholine; Zappia, V., Kennedy, E.P., Nilsson, B.I., Galletti, P., Eds.; Elsevier Science Publishing: Amsterdam, The Netherlands, 1985; pp. 317-327.

49. Watanabe, S.; Kono, S.; Nakashima, Y.; Mitsunobu, K.; Otsuki, S. Effects of various cerebral metabolic activators on glucose metabolism of brain. Folia Psychiat. Neurol. Jpn. 1975, 29, 67-76. [CrossRef] [PubMed]

50. Alberghina, M.; Giuffrida-Stella, A.M. Changes of phospholipid metabolizing and lysosomal enzymes in hypoglossal nucleus and ventral horn motoneurons during regeneration of craniospinal nerves. J. Neurochem. 1988, 51, 15-20. [CrossRef]

51. Arrigoni, E.; Averet, N.; Cohadon, F. Effects of CDP-choline on phospholipase A2 and cholinephosphotransferase activities following a cryogenic brain injury in the rabbit. Biochem. Pharmacol. 1987, 36, 3697-3700. [CrossRef]

52. Freysz, L.; Golly, F.; Mykita, S.; Avola, R.; Dreyfus, H.; Massarelli, R. Metabolism of neuronal cell culture: Modifications induced by CDP-choline. In Novel Biochemical, Pharmacological and Clinical Aspects of Cytidinediphosphocholine; Zappia, V., Kennedy, E.P., Nilsson, B.I., Galletti, P., Eds.; Elsevier Science Publishing: Amsterdam, The Netherlands, 1985; pp. 117-125.

53. Massarelli, R.; Mozzi, R.; Golly, F.; Hattori, H.; Dainous, F.; Kanfer, J.N.; Freysz, L. Synthesis de novo of choline, production of choline from phospholipids, and effects of CDP-choline on nerve cell survival. Fidia Res. Ser. 1986, 4, $273-281$.

54. Kitazaki, T.; Ohta, Y.; Tsuda, M. Inhibition of membrane associated phospholipase A2 by CDP-choline. Jpn. Pharmacol. Ther. 1985, 13, 159-164.

55. Farooqui, A.A.; Litsky, M.L.; Farooqui, T.; Horrocks, L.A.. Inhibitors of intracellular phospholipase A2 activity: Their neurochemical effects and therapeutical importance for neurological disorders. Brain Res. Bull. 1999, 49, 139-153. [CrossRef]

56. Algate, D.R.; Beard, D.J.; Sacristán, A.; Ortíz, J.A.; Davies, J.E. Study on the effects of oral administration of CDP-choline on EEG changes and lethality induced by epidural compression in the anesthetised cat. Arzneimittelforschung 1983, 33, 1013-1016.

57. Hayaishi, O.; Ozawa, K.; Araki, C.; Ishii, S.; Kondo, Y. Biochemical studies of head injury and brain edema. Jpn. J. Med. Prog. 1961, 48, 519-539.

58. Kondo, Y. Experimental study of the therapeutic use of cytidine nucleotids for brain injury. Nihon Geka Hokan. 1968, 32, 489-505.

59. Tsuchida, T.; Nagai, M.; Hoshino, T.; Kamano, S.; Miyake, H. Treatment of head injuries with intermediate substances of metabolic cycle of brain. II. Basic study on metabolism of cytidine diphosphate choline. Brain Nerve 1967, 19, 1041-1045. [PubMed]

60. Boismare, F.; Le Poncin, M.; Le François, J.; Hacpille, L.; Marchand, J.C. Étude des effets de l'administration de cytidinediphosphocholine sur les consèquences hémodynamiques, fonctionelles et biochimiques du traumatisme crâniocervical chez le rat. Thérapie 1977, 32, 345-354. [PubMed]

61. Clendenon, N.R.; Palayoor, S.T.; Gordon, W.A. Influence of CDP-choline on ATPase activity in acute experimental spinal cord trauma. In Novel Biochemical, Pharmacological and Clinical Aspects of Cytidinediphosphocholine; Zappia, V., Kennedy, E.P., Nilsson, B.I., Galletti, P., Eds.; Elsevier Science Publishing: Amsterdam, The Netherlands, 1985; pp. 275-284.

62. Cohadon, F.; Rigoulet, M.; Guérin, B.; Vandendriessche, M. Edème cérébral vasogénique. Altérations des ATPases membranaires. Restauration par un précurseur des phospholipides. Nouv. Presse Med. 1979, 8, 1589-1591.

63. Lafuente, J.V.; Cervós-Navarro, J. Estudio por microgavimetría del efecto de la CDP-colina en el edema cerebral experimental inducido por radiaciones ultravioletas. Med. Clin. 1986, 87 (Suppl. 1), 5-8. 
64. Cervós-Navarro, J.; Lafuente, J.V. Effect of cytidine diphosphate choline on ultraviolet-induced brain edema. Adv. Neurol. 1990, 52, 421-429. [PubMed]

65. Majem, X.; Bidón-Chanal, A.; Vilá-Badó, J. Estudio de los efectos del tratamiento oral con CDP-colina sobre los cambios inducidos por el edema encefálico experimental en el electroencefalograma de la rata no anestesiada. Med. Clin. 1986, 87 (Suppl. 1), $23-25$.

66. Roda, J.E. Répartition macro et microscopique d'un oedème cérébral vasogenique experimental. In Symposium International: Souffrance Cérébrale et Précurseurs des Phospholipides; Laboratoires Cassenne-Takeda: Paris, France, 1980.

67. Schmidt, K.; Hernekamp, J.F.; Doerr, M.; Zivkovic, A.R.; Brenner, T.; Walther, A.; Weigand, M.A.; Hofer, S. Cytidine-5diphosphocholine reduces microvascular permeability during experimental endotoxemia. BMC Anesthesiol. 2015, 15, 114. [CrossRef] [PubMed]

68. Hernekamp, J.F.; Hu, S.X.; Schmidt, V.J.; Vogelpohl, J.; Kneser, U.; Kremer, T. Influence of Cdp-Choline Administration on Early Burn Edema in Rats. Ann. Plast. Surg. 2015, 75, 388-392. [CrossRef]

69. Dixon, C.E.; Ma, X.; Marion, D.W. Effects of CDP-choline treatment on neurobehavioral deficits after TBI and on hippocampal and neocortical acetylcholine release. J. Neurotrauma 1997, 14, 161-169. [CrossRef]

70. Plataras, C.; Tsakiris, S.; Angelogianni, P. Effect of CDP-choline on brain acetylcholinesterase and Na(+), K(+)-ATPase in adult rats. Clin. Biochem. 2000, 33, 351-357. [CrossRef]

71. Başkaya, M.K.; Doğan, A.; Rao, A.M.; Dempsey, R.J. Neuroprotective effects of citicoline on brain edema and blood-brain barrier breakdown after traumatic brain injury. J. Neurosurg. 2000, 92, 448-452. [CrossRef]

72. Dempsey, R.J.; Raghavendra Rao, V.L. Cytidinediphosphocholine treatment to decrease traumatic brain injury-induced hippocampal neuronal death, cortical contusion volume, and neurological dysfunction in rats. J. Neurosurg. 2003, 98, 867-873. [CrossRef] [PubMed]

73. Menku, A.; Ogden, M.; Saraymen, R. The protective effects of propofol and citicoline combination in experimental head injury in rats. Turk Neurosurg. 2010, 20, 57-62. [PubMed]

74. Jacotte-Simancas, A.; Costa-Miserachs, D.; Coll-Andreu, M.; Torras-Garcia, M.; Borlongan, C.V.; Portell-Cortés, I. Effects of voluntary physical exercise, citicoline, and combined treatment on object recognition memory, neurogenesis, and neuroprotection after traumatic brain injury in rats. J. Neurotrauma 2015, 32, 739-751. [CrossRef]

75. Qian, K.; Gu, Y.; Zhao, Y.; Li, Z.; Sun, M. Citicoline protects brain against closed head injury in rats through suppressing oxidative stress and calpain over-activation. Neurochem. Res. 2014, 39, 1206-1218. [CrossRef] [PubMed]

76. Gan, D.; Wu, S.; Chen, B.; Zhang, J. Application of the Zebrafish Traumatic Brain Injury Model in Assessing Cerebral Inflammation. Zebrafish 2020, 17, 73-82. [CrossRef]

77. Cakir, E.; Usul, H.; Peksoylu, B.; Sayin, O.C.; Alver, A.; Topbas, M.; Baykal, S.; Kuzeyli, K. Effects of citicoline on experimental spinal cord injury. J. Clin. Neurosci. 2005, 12, 923-926. [CrossRef]

78. Yücel, N.; Cayli, S.R.; Ateş, O.; Karadağ, N.; Firat, S.; Turköz, Y. Evaluation of the neuroprotective effects of citicoline after experimental spinal cord injury: Improved behavioral and neuroanatomical recovery. Neurochem. Res. 2006, 31, 767-775. [CrossRef]

79. Coskun, C.; Avci, B.; Ocak, N.; Yalcin, M.; Dirican, M.; Savci, V. Effect of repeatedly given CDP-choline on cardiovascular and tissue injury in spinal shock conditions: Investigation of the acute phase. J. Pharm. Pharmacol. 2010, 62, 497-506. [CrossRef]

80. Turkkan, A.; Alkan, T.; Goren, B.; Kocaeli, H.; Akar, E.; Korfali, E. Citicoline and postconditioning provides neuroprotection in a rat model of ischemic spinal cord injury. Acta Neurochir. 2010, 152, 1033-1042. [CrossRef]

81. Galletti, P.; De Rosa, M.; Cotticelli, M.G.; Morana, A.; Vaccaro, R.; Zappia, V. Biochemical rationale for the use of CDPcholine in traumatic brain injury: Pharmacokinetics of the orally administered drug. J. Neurol. Sci. 1991, 103, S19-S25. [CrossRef]

82. Qureshi, I.; Endres, J.R. Citicoline: A novel therapeutic agent with neuroprotective, neuromodulatory, and neuroregenerative properties. Nat. Med. J. 2010, 2, 11-25.

83. Saver, J.L. Target brain: Neuroprotection and neurorestoration in ischemic stroke. Rev. Neurol. Dis. 2010, 7 (Suppl. 1), s14-s21.

84. Secades, J.J. Citicoline: Pharmacological and clinical review, 2016 update. Rev. Neurol. 2016, 63, S1-S73.

85. Alvarez-Sabín, J.; Román, G.C. The role of citicoline in neuroprotection and neurorepair in ischemic stroke. Brain Sci. 2013, 3, 1395-1414. [CrossRef]

86. Moriyama, M.; Tsukumo, T.; Nakagawa, Y. Effects of CDPcholine on head injury. Gendai No Rinsho 1967, 1, 114-120.

87. Misbach, J.; Andradi, S.; Harahap, T.P.; Soemargo, S.; Markam, S. Double blind trial of Nicholin (CDP-choline) on the patients with severe head injury. In Biannual Meeting of Neurology, Psychiatry and Neurosurgery; Surabaya, Indonesia, 1978.

88. Ayuso, J.L.; Saiz, J. Efecto protector del citidín-5-difosfato de colina sobre el defecto mnésico post-electrochoque. Munch. Med. Wochenschr. 1977, 119, 53-59.

89. De la Herrán, J.; Cortina, C.; Salazar, J.; de Monge, F. Utilización del citidín difosfato de colina en lesiones encefálicas graves. Actas Luso Esp. Neurol. Psiquiatr. Ciencias Afines. 1978, 6, 3-12.

90. Espagno, J.; Trémoulet, M.; Gigaud, M.; Espagno, C. Étude de l'action de la CDP-choline dans les troubles de la vigilance post-traumatique. Vie Médicale 1979, 3, 195-196.

91. Carcasonne, M.; LeTourneau, J.N. Étude en double insu du réxort en neurotraumatologie infantile. Vie Médicale 1979, $12,1007$.

92. Richer, E.; Cohadon, F. Essai thérapeutique d'un précurseur des phospholipides sur le traitement des comas traumatiques. In Symposium International: Souffrance cérébrale et Précurseurs des Phospholipides; Laboratoires Cassenne-Takeda: Paris, France, 1980. 
93. Lecuire, J.; Duplay, J. Sperimentazione in doppio cieco della citicolina versus meclofenossato in pazienti colpiti da trauma cranico. G. Ital. Ric. Clin. Ter. 1982, 3, 51-55.

94. Lecuire, J.; Duplay, J. Sperimentazione della citicolina in un camipone di 154 traumatizzati cranici. G. Ital. Ric. Clin. Ter. 1982, 3, 61-67.

95. Lecuire, J. Traumatismes crâniens: Étude comparative piracetam-CDP-choline. C. R. Ther. Pharmacol. Clin. 1985, 3, 3-7.

96. Cohadon, F.; Richer, E.; Poletto, B. Etude d'un precurseur des phospholipides dans le traitement des comas traumatiques graves (A precursor of phospholipids in the treatment of severe traumatic comas). Neurochirurgie 1982, 28, 287-290. [PubMed]

97. Deleuze, R.; Huguenard, P.; Laborit, G.; Roujas, F. Effets de la CDP-choline sur le rapport lactates/pyruvates dans le LCR en cas de souffrance cérébrale grave. C. R. Ther. 1985, 4, 11-18.

98. Ogashiwa, M.; Takeuchi, K.; Hara, M.; Tanaka, Y.; Okada, J. Studies on the intrathecal pharmacotherapy. Part I: CDP-choline. Int. J. Clin. Pharmacol. Biopharm. 1975, 12, 327-335.

99. Ogashiwa, M.; Takeuchi, K. Intrathecal pharmacotherapy in coma. Acta Neurochir. 1976, 34, 37-44. [CrossRef]

100. De Blas, A.; Martínez-Cubells, J.; Hernando, C. Valoración de la efectividad de la citicolina en el tratamiento de los traumatismos craneoencefálicos. Med. Clin. 1986, 87 (Suppl. 1), 41-44.

101. Ragguenneau, J.L.; Jarrige, B. Enquête nationale sur les suites des traumatismes crâniens graves: Analyse des 219 traumatismes traités par CDP-choline. Agressologie 1988, 29, 439-443.

102. Calatayud Maldonado, V.; Calatayud Pérez, J.B.; Aso Escario, J. Effects of CDP-choline on the recovery of patients with head injury. J. Neurol. Sci. 1991, 103, S15-S18. [CrossRef]

103. Lozano, R. CDP-choline in the treatment of cranio-encephalic traumata. J. Neurol. Sci. 1991, 103, S43-S47. [CrossRef]

104. Lazowski, T.; Kierul, K.; Bartnicki, M.; Mayzner-Zawadzka, E.; Toczylowska, B.; Ryba, M.; Lewandowski, Z. Effects of citicoline treatment in patients with isolated head trauma: A randomized trial. Critical Care 2003, 7 (Suppl. 2), 78. [CrossRef]

105. Hinev, S.; Tzoneva, D.; Ljubenova, K.; Tzvetkov, V.; Dimitrov, G.; Stefanov, I. Neuroprotection as component of complex therapy in patients with severe head trauma and cerebrovascular diseases. Anaesthesiol. Intensive Care 2007, 34, 19-24.

106. Krishna, D.; Chaurasia, I.D.; Jethwani, U. Role of citicoline in traumatic brain injury: A randomized controlled study. IJPMR 2012, $2,1-5$.

107. Zafonte, R.; Friedewald, W.T.; Lee, S.M.; Levin, B.; Diaz-Arrastia, R.; Ansel, B.; Eisenberg, H.; Timmons, S.D.; Temkin, N.; Novack, T.; et al. The citicoline brain injury treatment (COBRIT) trial: Design and methods. J. Neurotrauma 2009, 26, 2207-2216. [CrossRef] [PubMed]

108. Zafonte, R.D.; Bagiella, E.; Ansel, B.M.; Novack, T.A.; Friedewald, W.T.; Hesdorffer, D.C.; Timmons, S.D.; Jallo, J.; Eisenberg, H.; Hart, T.; et al. Effect of citicoline on functional and cognitive status among patients with traumatic brain injury: Citicoline Brain Injury Treatment Trial (COBRIT). JAMA 2012, 308, 1993-2000. [CrossRef]

109. El Reweny, E.M.; Okasha, A.; Hafez, A. The neuroprotective effect of citicholine (CDP choline) in patients with traumatic brain injury. In Proceedings of the 25th ESICM Annual Congress, Lisbon, Portugal, 13-17 October 2012.

110. Varadaraju, D.N.; Ananthakishan, A. Effect of cerebroprotein hydrolysate with citicoline versus citicoline alone in the initial management of head injury and its clinical outcome a prospective randomised comparative study. J. Evid. Based Med. Healthc. 2017, 4, 2835-2837.

111. Titov, I.I.; Voloshinsky, O.V.; Martin, A.Y.; Vintonyak, I.V.; Nestor, I.I. Evaluation of neuroprotectoral therapy efficiency in TBI. Pain Anesth. Intensive Care 2018, 3, 61-68.

112. Trimmel, H.; Majdan, M.; Wodak, A.; Herzer, G.; Csomor, D.; Brazinova, A. Citicoline in severe traumatic brain injury: Indications for improved outcome: A retrospective matched pair analysis from 14 Austrian trauma centers. Wien. Klin. Wochenschr. 2018, 130, 37-44. [CrossRef] [PubMed]

113. Ahmadi, J.; Hoseinzadeh-Chahkandak, F.; Roobiyat, M.Y.; Pourbagher-Shahri, A.M.; Irankhah, S.; Rajabpour-Sanati, A. Comparison of two different doses of citicoline in patients with traumatic brain injury. J. Surg. Trauma 2020, 8, 8-15.

114. Salehpour, F.; Shokouhi, G.; Shakeri, M.; Shimia, M.; Mahdkhah, A.; Baradaran, A.; Imani, M.T.; Mirzaee, F.; Azar, A.K.; Bazzazi, A.M.; et al. Neuroprotective effects of citicoline in diffuse axonal injuries. Adv. Biosci. Clin. Med. 2013, 1, 12-15.

115. Salehpour, F.; Aghazade, J.; Mirzaee, F.; Mahdkhah, A. Citicoline in patients with traumatic brain injuries. EC Neurol. 2015, 2 , 87-93.

116. Shokouhi, G.; Haghjoo, A.G.; Sattarnezhad, N.; Asghari, M.; Sattarnezhad, A.; Asghari, A.; Pezeshki, A. Effects of citicoline on level of consciousness, serum level of fetuin-A and matrix Gla-protein (MGP) in trauma patients with diffuse axonal injury (DAI) and GCS $\leq 8$. Ulus Travma Acil. Cerrahi. Derg. 2014, 20, 410-416. [CrossRef]

117. Levin, H.S. Treatment of postconcussional symptoms with CDP-choline. J. Neurol. Sci. 1991, 103, S39-S42. [CrossRef]

118. Aniruddha, T.J.; Pillai, S.; Devi, B.I.; Sampath, S.; Chandramouli, B.A. Role of citicoline in the management of mild head injury. Indian J. Neurotrauma 2009, 6, 49-52.

119. Jotwani, V.; Harmon, K.G. Postconcussion syndrome in athletes. Curr. Sports Med. Rep. 2010, 9, 21-26. [CrossRef]

120. León-Carrión, J.; Domínguez-Roldán, J.M.; Murillo-Cabeza, F.; Domínguez-Morales, M.R.; Muñoz-Sánchez, M.A.; Forastero, P. Advances in the treatment of memory deficits after brain injury: The role of citicholine. In Proceedings of the 3rd World Congress on Brain Injury, Quebec City, QC, Canada, 12-17 June 1999. 
121. León-Carrión, J.; Domínguez-Roldán, J.M.; Murillo-Cabeza, F.; Domínguez-Morales, M.R.; Muñoz-Sánchez, M.A. Normalization of memory-related cerebral blood flow in severe traumatic brain injury patients and improvements of memory induced by citicholine (CDP-choline): The role of a pro-cognitive drug. In Proceedings of the International Conference on Recent Advances in Neurotraumatology, ICRAN'99, Taipei, Taiwan, 20-23 November 1999.

122. León-Carrión, J.; Domínguez-Roldán, J.M.; Murillo-Cabeza, F.; Domínguez-Morales, M.R.; Muñoz-Sánchez, M.A. The role of citicholine in neuropsychological training after traumatic brain injury. Neurorehabilitation 2000, 14, 33-40. [CrossRef]

123. Wortzel, H.S.; Arciniegas, D.B. Treatment of post-traumatic cognitive impairments. Curr. Treat. Options Neurol. 2012, 14, 493-508. [CrossRef]

124. Spiers, P.A.; Hochanadel, G. Citicoline for traumatic brain injury: Report of two cases, including my own. J. Int. Neuropsychol. Soc. 1999, 5, 260-264. [CrossRef]

125. Secades, J.J. Citicoline for the Treatment of Head Injury: A Systematic Review and Meta-analysis of Controlled Clinical Trials. J. Trauma. Treat 2014, 4, 227. [CrossRef]

126. El Sayed, I.; Zaki, A.; Fayed, A.M.; Shehata, G.M.; Abdelmonem, S. A meta-analysis of the effect of different neuroprotective drugs in management of patients with traumatic brain injury. Neurosurg. Rev. 2018, 41, 427-438. [CrossRef] [PubMed]

127. Fioravanti, M.; Yanagi, M. Cytidinediphosphocholine (CDP-choline) for cognitive and behavioural disturbances associated with chronic cerebral disorders in the elderly. Cochrane Database Syst. Rev. 2005, 2, CD000269. [CrossRef] [PubMed]

128. Mondello, S.; Hasan, A.; Shear, D.A. Editorial: Developing Successful Neuroprotective Treatments for TBI: Translational Approaches, Novel Directions, Opportunities and Challenges. Front. Neurol. 2019, 10, 1326. [CrossRef] [PubMed]

129. Lerouet, D.; Marchand-Leroux, C.; Besson, V.C. Neuropharmacology in traumatic brain injury: From preclinical to clinical neuroprotection? Fundam. Clin. Pharmacol. 2021. [CrossRef]

130. Rajguru, M.; Agrawal, A.; Sampath Kumar, N.S.; Amil Kumar, T. An overview of clinical and therapeutic implications of citicoline. Narayana Med. J. 2014, 3, 54-60. 